\title{
Multiphase boudinage: a case study of amphibolites in marble in the Naxos migmatite core
}

\author{
Simon Virgo, Christoph von Hagke, and Janos L. Urai \\ Structural Geology, Tectonics and Geomechanics, RWTH Aachen University, Lochnerstrasse 4-20, 52056 Aachen, Germany \\ Correspondence: Simon Virgo (s.virgo@ged.rwth-aachen.de)
}

Received: 15 August 2017 - Discussion started: 23 August 2017

Revised: 18 December 2017 - Accepted: 20 December 2017 - Published: 15 February 2018

\begin{abstract}
In multiply deformed terrains multiphase boudinage is common, but identification and analysis of these is difficult. Here we present an analysis of multiphase boudinage and fold structures in deformed amphibolite layers in marble from the migmatitic centre of the Naxos metamorphic core complex. Overprinting between multiple boudinage generations is shown in exceptional 3-D outcrop. We identify five generations of boudinage, reflecting the transition from high-strain high-temperature ductile deformation to medium- to low-strain brittle boudins formed during cooling and exhumation. All boudin generations indicate E-W horizontal shortening and variable direction of bedding parallel extension, evolving from subvertical extension in the earliest boudins to subhorizontal $\mathrm{N}-\mathrm{S}$ extension during exhumation. Two phases of E-W shortening can be inferred, the first associated with lower crustal synmigmatic convergent flow and the second associated with exhumation and $\mathrm{N}-\mathrm{S}$ extension, possibly related to movement of the North Anatolian Fault.
\end{abstract}

\section{Introduction}

Boudins are periodic deformation structures that form in mechanically layered rocks under layer normal shortening and layer parallel extension (Marques et al., 2012; Ramberg, 1955). Since their earliest description (Harker, 1889; Lohest, 1909; Ramsay, 1881) and initial confusion in nomenclature of mullions and boudins (Kenis et al., 2002; Kenis and Sintubin, 2002), the understanding of these structures has greatly improved, and a taxonomy was established to describe the diversity of observed boudin structures (Goscombe et al., 2004). Although boudins are often depicted in two dimen- sions, it has been shown that in three dimensions boudins can be complex (Abe et al., 2013; Marques et al., 2012; Zulauf et al., 2011b). This complexity can be distinctive when boudins are the result of more than one deformation event. Some multiphase structures such as mullions or bone boudins are indicative of a specific sequence of deformation (Kenis et al., 2005; Maeder et al., 2009). Chocolate tablet boudins form by two phases of extension of layers in different directions (Abe and Urai, 2012; Ghosh, 1988; Zulauf et al., 2011a, b), and have been used to analyse the deformation history of rocks (Casey et al., 1983; Marques et al., 2010; Reber et al., 2010). However, in the majority of studies of boudinage, the possibility of more than one generation of boudinage is not discussed (Goscombe et al., 2004). Considering the number of studies that have utilized crosscutting shear zones, veins or superimposed folds for the reconstruction of multiply deformed domains, the use of polyphase boudinage for this purpose has not yet been used to its full potential. We propose that their ubiquity and rich structure (Goscombe and Passchier, 2003; Ingram and Urai, 1999; Maeder et al., 2009; Schmalholz et al., 2008; Schmalholz and Maeder, 2012; Van Noten and Sintubin, 2010; Zulauf and Zulauf, 2005) with a large spectrum of deformation mechanisms, from brittleductile rupture to ductile localization, provide the potential for extending this toolbox in structural geology (see Mandal et al., 2007).

This paper builds on a study of boudinaged pegmatites in the marbles of the migmatite core of Naxos (Schenk et al., 2007). Schenk et al. (2007) proposed that Mode-I interboudin fractures formed at lithostatic fluid pressure conditions after solidification of the pegmatite. Decreasing pore fluid pressures under continuing N-S extension of the pegmatite inhibited further opening-mode deformation in the inter-boudin 
zones and consequently the boudin blocks rotated during deformation of the surrounding marble.

In this study, we focus on polyphase deformation of amphibolite layers in the marbles. In addition to blocky boudinage which also occurs in the pegmatites, the amphibolite layers record higher-temperature deformation, as witnessed by pinch-and-swell boudins. Combining field data with microstructural analysis we link the different boudin generations to rheology and metamorphic conditions. Furthermore, since the amphibolites are older than the pegmatites, they record a longer deformation history and provide insights into the tectonic evolution of the Aegean, specifically the nature of east-west shortening of the domain, recognized by several authors (Urai et al., 1990; Ring and Layer, 2003; Jolivet and Brun, 2010; Hinsbergen and Schmid, 2012; Menant et al., 2013; Malandri et al., 2017) .

\section{Geological setting}

The island of Naxos is located in the Aegean Sea. This region has experienced back-arc extension since the Eocene due to retreat of the Hellenic subduction zone towards the southwest (Gautier et al., 1999; Grasemann et al., 2011; Jolivet and Brun, 2010). This long-lived slab roll-back makes the region one of the prime targets for understanding subduction dynamics and associated exhumation of HP and UHP rocks, as well as for understanding the evolution of metamorphic core complexes. The Cycladic islands have all undergone complex metamorphic evolution related to a lithosphere-scale detachment system. The main detachment system (North Cycladic Detachment System) can be followed across the entire Aegean Sea, but is interrupted by the Mid-Cycladic Lineament north of Paros and Naxos (Walcott and White, 1998b).

Naxos is the largest of the Aegean islands and one of the classic examples of a metamorphic core complex (Lister et al., 1984). Situated in the footwall of the North Cycladic detachment system and exposing a rich variety in lithologies and metamorphic facies, Naxos has been the subject of many studies to understand the tectonic history of the Aegean domain and the evolution of rheology under changing metamorphic grade (Buick, 1991; Gautier et al., 1993; Jansen, 1973; Jansen and Schuiling, 1976; Jolivet et al., 1994, 2004, 2010; Keay et al., 2001; Urai et al., 1990; Urai and Feenstra, 2001; Krabbendam et al., 2003; Schenk et al., 2005).

The geology of Naxos is dominated by a N-S-trending elliptical structural and metamorphic dome, comprised of marble, metavolcanics, metabauxites and metapelitic schists of Permo-Triassic age (Andriessen et al., 1979) (Fig. 1). The present-day metamorphic facies distribution is the result of at least three distinct metamorphic phases associated with Alpine deformation (Urai et al., 1990). The first metamorphic event at high-pressure, low-temperature conditions is associated with top-to-south shearing in the Hellenic subduction zone (D1), and formation of the Hellenides at approximately $50 \mathrm{Ma}$ (Andriessen et al., 1979; Dürr et al., 1978; Urai et al.,

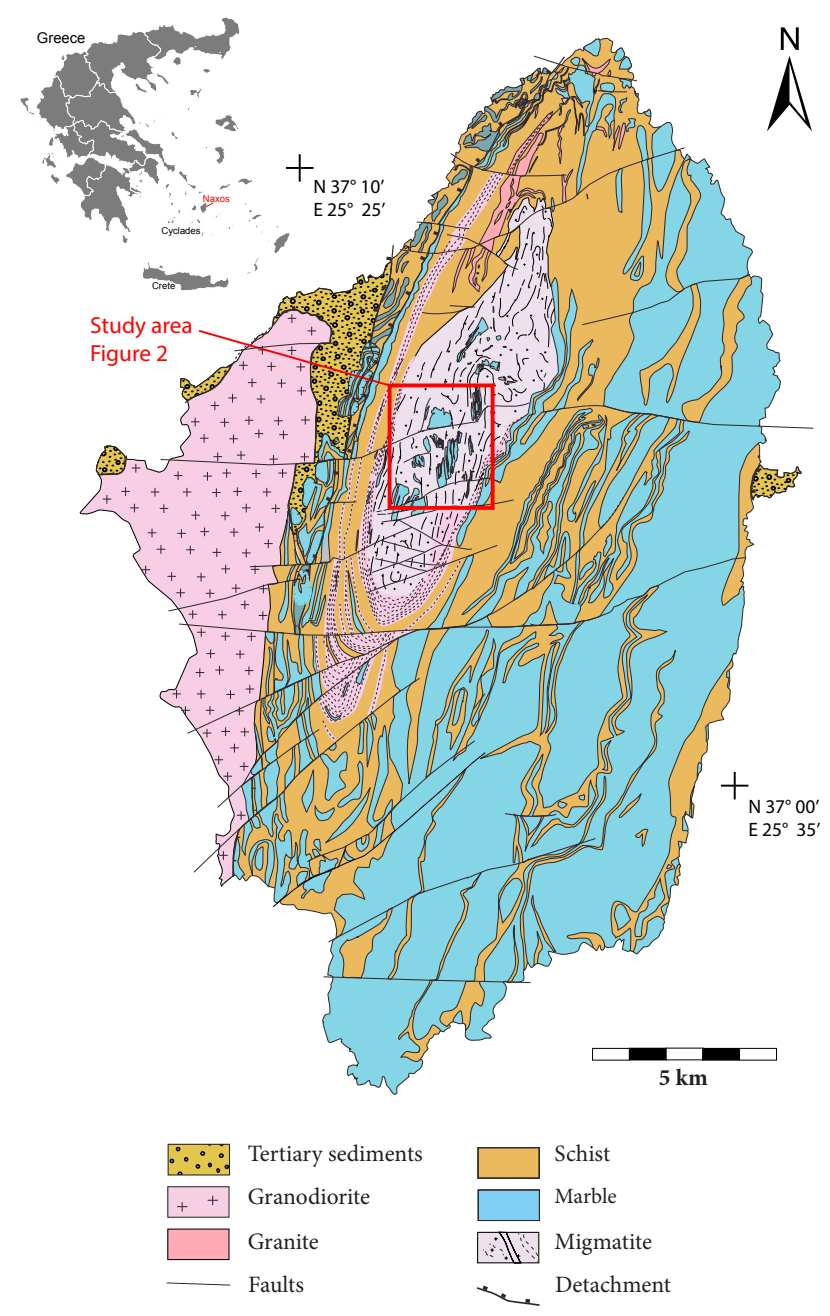

Figure 1. Geological map of Naxos, modified after Jansen (1993), Vanderhage (2004) and Kruckenberg et al. (2011). The study area (red box) is located in the central migmatitic core of the Naxos metamorphic core complex.

1990; Wijbrans and McDougall, 1988). Large-scale isoclinal folds and other deformation structures formed during D1 were overprinted by top-to-north shearing of D2, starting at the onset of crustal thinning and post-orogenic extension in the early Miocene (Mercier et al., 1976; Ring et al., 2010; Urai et al., 1990). As a consequence of crustal thinning and extension of the Aegean domain, the rocks of Naxos were overprinted by regional-scale greenschist metamorphism at $\sim 25 \mathrm{Ma}\left(\mathrm{M} 2_{a}\right)$, and more localized high-temperature, lowpressure metamorphism $\left(\mathrm{M} 2_{b}\right)$ with thermal dome formation and partial anatexis at $\sim 16 \mathrm{Ma}$ (Duchene et al., 2006; Keay et al., 2001; Martin et al., 2006, 2008). The metamorphic grade of $\mathrm{M} 2{ }_{b}$ decreases from a high-grade migmatitic core down to greenschist facies along its fringes (Jansen and Schuiling, 1976). The estimated 50-70 km top-to-north shearing of the North Cycladic detachment (Brichau et al., 2006; Jolivet et al., 2004, 2010) is reflected by a pervasive N- 
S lineation and shallowly dipping foliation warping around the metamorphic dome. On a larger scale, $\mathrm{N}-\mathrm{S}$-trending tight and isoclinal, coaxially refolded folds (B1 and B2) with fold axes commonly parallelized to the $\mathrm{N}-\mathrm{S}$ lineation during shearing. A late stage of upright open folds (B3) deform the axial plane foliation of B1 and B2 (Buick, 1991; Jansen, 1977; Urai et al., 1990), indicating E-W shortening. On the smaller scale, D2 deformation manifests in a large variety of structures in the various metamorphic grades and lithologies. In recent years, several studies have addressed deformation structures in the high-grade magmatic core, and it was shown that structures in the migmatite dome formed through viscoplastic flow in synmigmatic $\mathrm{M} 2_{b}$ conditions (Kruckenberg et al., 2010, 2011; Rey et al., 2011). In the later stages of the $\mathrm{M} 2{ }_{b}$ metamorphism, pegmatite dikes intruded the marble (e.g. Buick, 1991). The complex tectonic history is reflected in $\mathrm{U}-\mathrm{Pb}$ ages from zircon in amphibolites, which show inherited old cores and two phases of later overgrowth at 40 and 15-14 Ma, respectively (Bolhar et al., 2016). These ages may be interpreted either as early intrusion, during oceanization of the Aegean, or as late emplacement during large-scale extension (Bolhar et al., 2016). Zircon and apatite fission track data from all tectonic units exposed on Naxos as well as U$\mathrm{Pb}$ ages show a consistent cooling and exhumation scenario: cooling started at $\sim 25 \mathrm{Ma}$, and continued until $\sim 8 \mathrm{Ma}$ (Seward et al., 2009; Brichau et al., 2006; John and Howard, 1995; Cao et al., 2017).

Structures in the central migmatite dome show several synmigmatic subdomes (Vanderhaeghe, 2004) (Fig. 2). Within the mantling sequence around the migmatite dome, mylonitic shear zones (Krabbendam et al., 2003; Renjith et al., 2016) indicate relative upward movement of the migmatite while progressive transposition and folding of granitic dikes result from vertical flattening and top-to-NNE shearing during dome formation (Vanderhaeghe, 2004). Outcrop-scale mapping and analysis of the magnetic fabric of the internal structure of the migmatite revealed two compartments of subdomes separated by a N-S-trending high-strain zone, which contains kilometre-scale rafts of marble folded into pinched synforms (Kruckenberg et al., 2010, 2011, Fig. 1). The authors conclude that an interplay between buoyancy and isostasy-dominated flow is responsible for the complex internal structure of the migmatite, and dome formation was driven by upper crustal extension and shearing with coeval lower crustal E-W convergent flow.

\section{Methods}

The field data presented in this study were collected in active and recently abandoned marble quarries in the central hills of Naxos, in the vicinity of Kinidaros (Fig. 2). As a result of the mining activities outcrop conditions are exceptional, with large and unweathered vertical and horizontal saw-cut surfaces (Fig. 3). Orientation data were collected in situ using

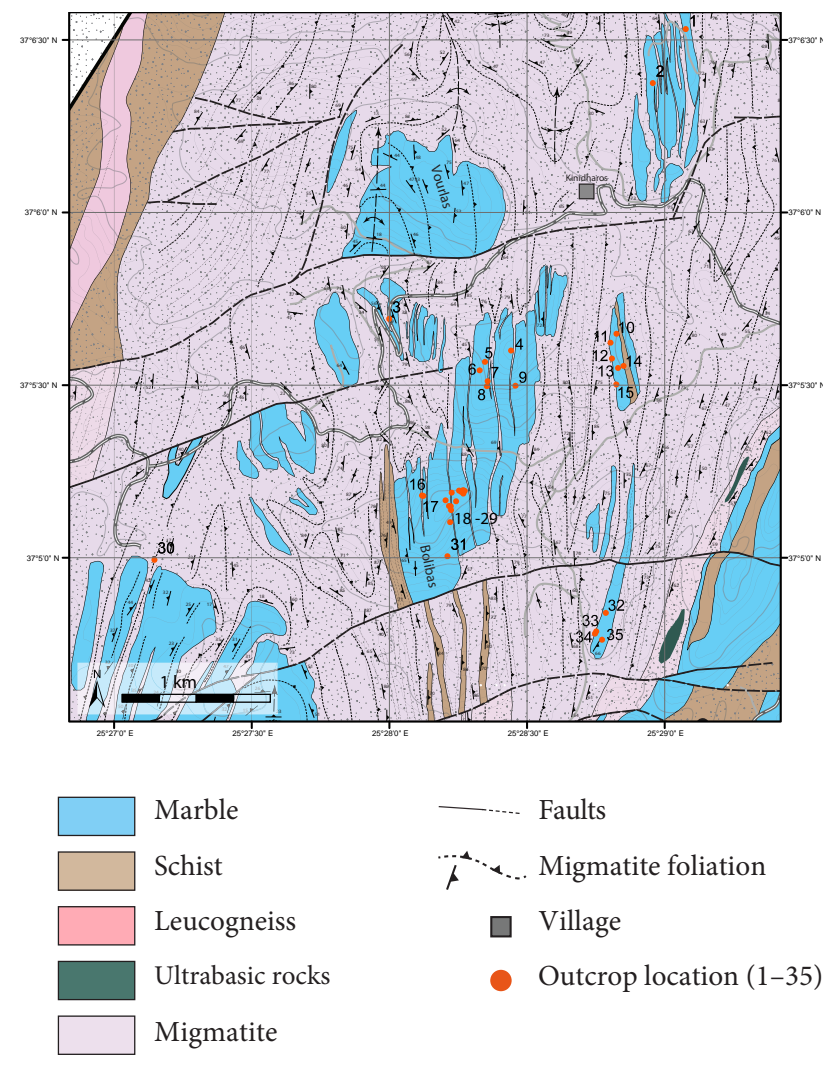

Figure 2. Geological map of the study area with outcrop locations (1-35), modified after Kruckenberg et al. (2011). Most outcrops visited in this study are situated in the central high-strain zone of the migmatite complex.

a Breithaupt structural compass. Measurements were taken only where sufficient topography allowed for unambiguous identification of the orientation of structures. For planar, saw cut surfaces this is only possible at corner intersections. Often the marble is conveniently broken off along the amphibolite layers, which allows for precise measurements. We use crosscutting and interaction relationships to establish a relative temporal order of the structural elements. Parts of the age relationship observations were conducted in mined blocks in the quarry. The exact origin of these blocks in the quarry is not known. However, the orientation of the blocks can be constrained, as the faces are always cut either subvertically or subhorizontally, and the orientation of the amphibolite layers and most structures was found to be consistent throughout the quarry. We used these blocks for analysis of overprinting relations and for sampling for microstructural analysis in plane-polarized and cross-polarized transmitted light using the Virtual Petrography (ViP) microscope (Virgo et al., 2016). 


\section{Results}

We have identified six types of outcrop-scale deformation structures in the study area (Figs. 3, 4): two generations of pinch-and-swell structures (Fig. 5), folds (Fig. 6), and three generations of boudins (domino boudins, torn boudins and hairline veins, Fig. 7). The definition of the term "boudinage" used in this study comprises all periodic layer-parallel extension structures of competent layers in a less competent matrix (e.g. Ramberg, 1955; Price and Cosgrove, 1990; Pollard and Fletcher, 2005). In addition to the discrete boudins separated by planar fracture faces, this comprises also pinchand-swell structures, which form by continuous necking (e.g. Schmalholz et al., 2008). We use the term "pinch and swell" rather than "drawn boudins" (Goscombe et al., 2004) to comply with the established terminology. We additionally include a distinct variety of hairline veins.

In addition to boudinage and folding, the marbles are affected by late deformation structures such as rare mylonitic shear zones and brittle normal- to oblique-slip faults (Fig. 5c) that have been described by Schenk et al. (2005), Buick (1991), Cao et al. (2017) and Vanderhaeghe (2004). In the following we give a short overview of the properties and microstructure of the marble and amphibolite before we describe the different generations of boudins and folds in more detail. For the description of the boudin structures and geometries we follow the terminology of Goscombe et al. (2004).

\subsection{Marble}

The marbles of the migmatite core are characterized by their mineralogical purity and large grain size. The bulk grain size of the marble in the study area is the largest observable on the island with grain diameters up to $20 \mathrm{~mm}$ (Covey-Crump and Rutter, 1989; Ebert et al., 2009). The marbles are diffusely banded with centimetre- to metre-scale bands of lighter and darker grey marble. White bands often occur adjacent to amphibolites. Around some amphibolites an orange-red staining of the marble from iron oxides can be observed predominantly along grain boundaries. The bulk marble appears to have an isotropic texture (due to the large grain size of the calcite a statistical analysis of the crystal preferred orientation is impractical and was not performed); however, the quarrymen report a $\mathrm{N}-\mathrm{S}$-trending vertical preferred fracturing of the marble in mining operations, which might indicate a grain-scale anisotropy. This is in line with foliation normal to CPO as reported by Ebert et al. (2009). The dominant marble microstructure is characteristic of dynamic recrystallization at high temperature (Fig. 8c): amoeboid grains with lobate grain boundaries and orientation families indicating extensive grain boundary migration (Urai and Feenstra, 2001). In triple junctions, angles between grain boundaries are typically $\sim 120^{\circ}$. Subgrain boundaries are less common. The overall grain size distribution is heterogeneous and bimodal: the majority of grains are between 300 and $600 \mu \mathrm{m}$ in 2-D sections. Exceptionally large grains $(>10 \mathrm{~mm})$, which occur locally in some layers, are interpreted to have formed by exaggerated grain growth during dynamic recrystallization. The vast majority of calcite grains in the marble show twinning, undulose extinction and local grain boundary migration recrystallization (in the boudin necks of domino boudins; see below) to fine grain size as a consequence of low-temperature deformation overprint.

\subsection{Amphibolite}

Amphibolite layers are by far the most common inclusion in the marbles; pegmatite dikes and bodies of felsic schists are much less frequent. In the study area amphibolite layers consistently strike $\mathrm{N}-\mathrm{S}$ with dips from vertical in some quarries to less steep $\left(\sim 60^{\circ}\right)$ to the east in others (Location 10 15 and 32-35, Fig. 2). Spacing of the layers is in the range of tens of centimetres to several metres and their thickness is usually less than $20 \mathrm{~cm}$. The bulk mineralogy of the amphibolites consists of mostly hornblende (tschermakite) and plagioclase (andesine) with muscovite, biotite, and accessorial titanite (Schenk et al., 2007). The interface of marble and amphibolite is well defined. Some layers show internal layering at the scale of a few centimetres caused by variation of plagioclase content. The foliation sometimes present in the amphibolites (for example in the hinges of folds) results from compositional variations and not from preferred orientation. In all thin sections the amphibolite has an apparently isotropic microstructure, even in zones where high strains can be inferred (e.g. in fold hinges and in the pinches of pinch-and-swell boudins). We interpret this as an indication for static recrystallization of the amphibolite after high-strain deformation, erasing the fabric of earlier dynamic recrystallization by static grain growth (Cees Passchier, personal communication, 27 April 2017). Indicators of low-strain deformation of the bulk amphibolite are minor undulose extinction in feldspars and amphibole grains fractured along their cleavage planes.

Nearly all amphibolite layers are boudinaged and at least five different types of boudins can be distinguished based on outcrop and thin section which are described in detail below. It is interesting to note that very thin layers of amphibolite $(<5 \mathrm{~mm})$ only show discernible boudinage if they are very close to a thicker amphibolite layer to form harmonic boudins. As single layers, these very thin amphibolites do not boudinage but deform homogeneously with the surrounding marble (Fig. 7e).

\subsection{Long-wavelength pinch and swell}

The boudin generation that is overprinted by all other structures is long-wavelength pinch-and-swell boudinage $(l \lambda) . l \lambda$ can only be found in layers thicker than $\sim 5 \mathrm{~cm}$, and due to the long wavelength they can best be observed and measured 

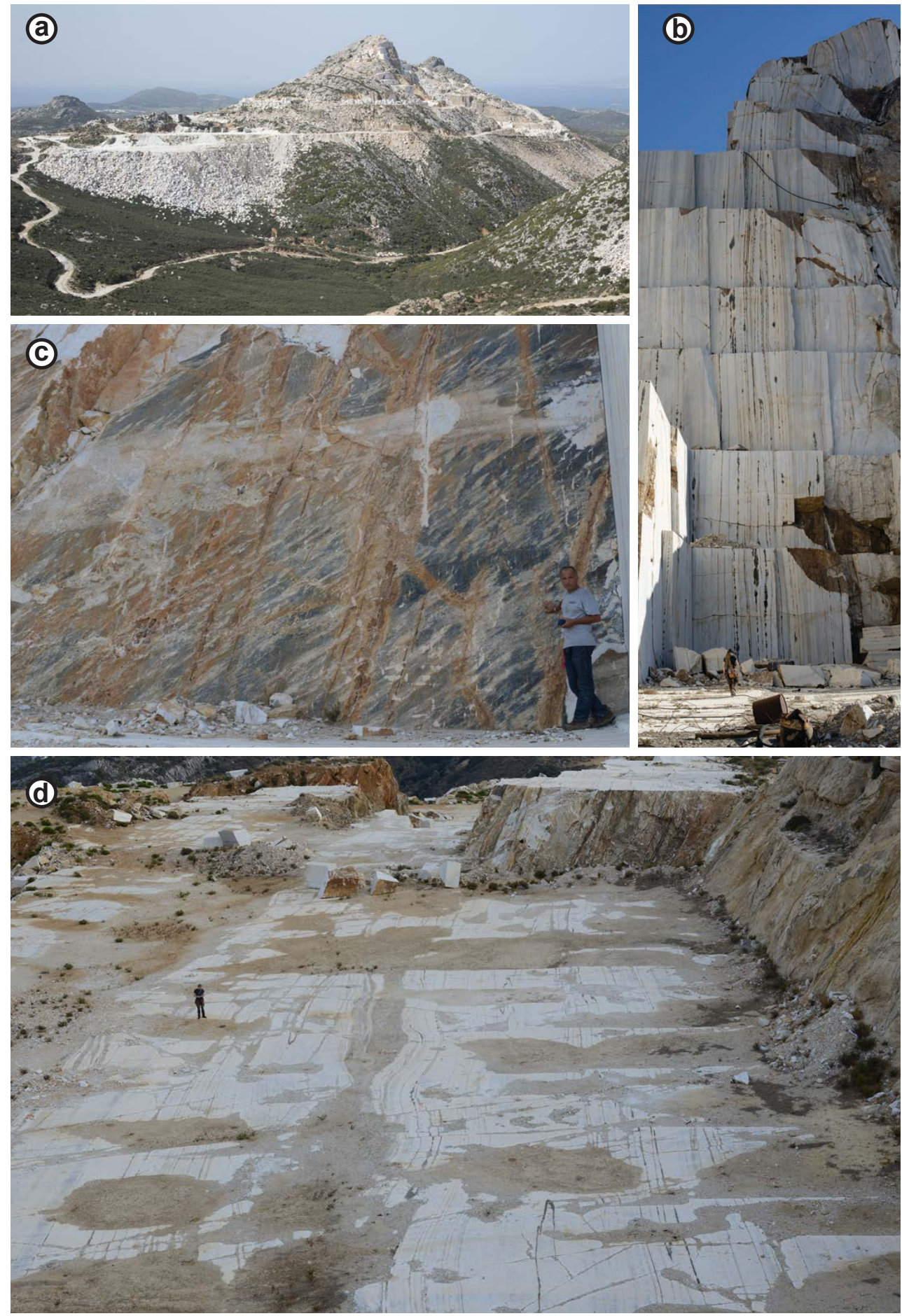

Figure 3. Excellent outcrop conditions in marble quarries allow for detailed observation of the boudinaged amphibolite at vertical and horizontal faces. All images contain a geologist for scale. (a) View to the west on Mount Bolibas, hosting the largest quarry in the area (Location 16-29). (b) Inside the Bolibas quarry, view to the south. The subvertical N-S striking amphibolites can be followed over all soles of the quarry. This section exposes mostly pinch-and-swell boudins. (c) View to the west on an amphibolite surface (Location 31). Layerparallel cuts like this are essential for age relationship observations and expose the subhorizontal necks of the $l \lambda$ pinch-and-swell boudins, which are hard to identify in layer-normal cuts. (d) Recently abandoned quarry in the south of the field area (Location 32-35) exposing many folds, brittle boudins and a large boudinaged inclusion of schist across a football-field-sized horizontal surface. 
0 . Amphibolite layers are plotted as great circles

1. Long wavelength pinch-and-swell (1 $1 \lambda)$
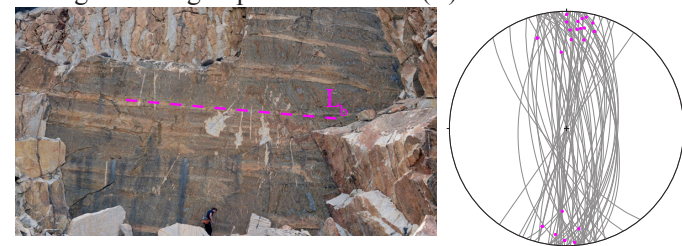

2. Short wavelength pinch-and-swell ( $\mathrm{s} \lambda$ )
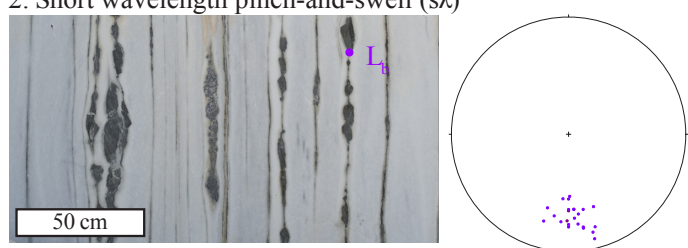

3. Asymmetric folds
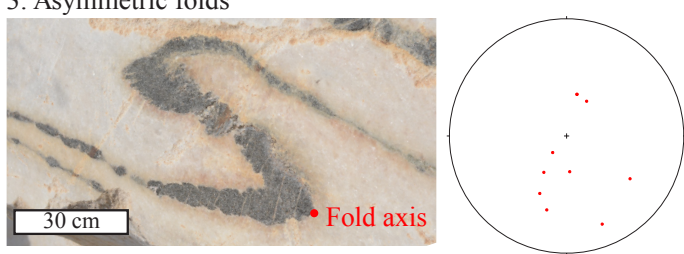

4. Domino boudins
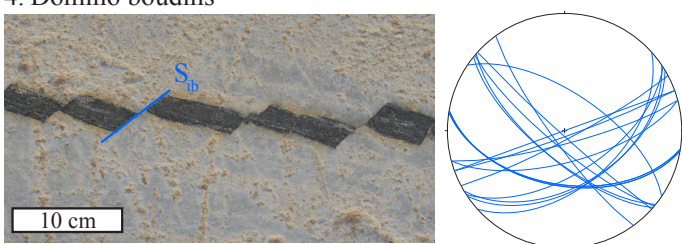

5. Torn boudin
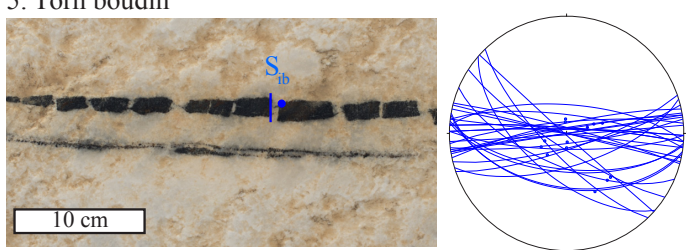

6. Hairline veins
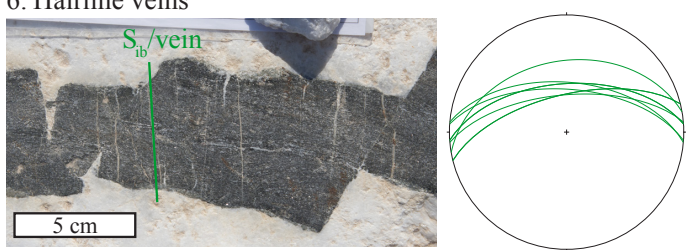

Figure 4. Overview of the structures found in the study area and their orientation plotted in stereonets (lower hemisphere). Images on the left show typical examples of the structures in the field. Indicators highlight the component of the structure that is shown in the stereonet: amphibolite layers are plotted as great circles (1). Pinchand swell boudins $(1,2)$ do not have boudin faces, therefore the long axis of the boudin $\left(L_{\mathrm{b}}\right)$ is plotted. Folds are represented by their fold axis (3). The plane of the boudin face $S_{\mathrm{b}}$ is plotted for domino boudins (4) and torn boudins (5) and hairline veins (6) are shown as great circles. on large N-S-trending layer-parallel outcrop faces that expose the amphibolite layer (Figs. 3c, 9). The thickness of the amphibolite is reduced to locally less than a millimetre in the pinches, but a full disruption of the amphibolite (tapering boudins) was never observed. The amphibolite does not show an obvious crystallographic or shape-preferred orientation - neither in the pinches, nor in the swells despite considerable strain (this indicates static recrystallization of the amphibolite after pinch-and-swell boudinage). The trace of the boudins (the lineation of the boudin necks $\left(L_{\mathrm{b}}\right)$, Goscombe et al., 2004) is consistently subhorizontal throughout the study area, indicating vertical extension of the layers. Wavelength $\lambda$ of the boudinage correlates with amphibolite thickness and can reach several metres for amphibolites with a thickness over $10 \mathrm{~cm}$. Estimated from the combined length of the pinches and swells $((L+M) / L)$ the amount of layerparallel extensional strain is at least $100 \%$.

\subsection{Short-wavelength pinch and swell}

Pinch-and-swell boudins with a much shorter wavelength $(s \lambda)$ overprint $l \lambda$ (Fig. 9a, c, d). In many layers $s \lambda$ is only developed in the $l \lambda$ swells. However, clear age relationships can be observed where $s \lambda$ boudins are present and well exposed in the swells as well as the high-strain pinches of $l \lambda$ : in both $s \lambda$ boudin necks have the same orientation (Fig. 10) indicating that $s \lambda$ is younger than $l \lambda$ : the lineation of boudin necks $\left(L_{\mathrm{b}}\right)$ dips $20-45^{\circ}$ to the south and intersects with the local $l \lambda$ boudin necks at an angle of $>20^{\circ}$. If $l \lambda$ was younger than $s \lambda$, given the amount of strain of $l \lambda$ and misorientation between $s \lambda$ and $l \lambda$, the orientation of $s \lambda$ necks would have rotated in the $l \lambda$ necks, which was never observed. Within the same layer, the wavelength of $s \lambda$ is commonly less than half the wavelength of the $l \lambda$ pinch-and-swell boudins.

The swells of $s \lambda$ are mostly symmetric with convex exterior planes and can be classified as drawn boudins and tapering boudins following the classification scheme by Goscombe et al. (2004). Occasionally fish mouth terminations are found (Fig. 11c). Neither in thinned out pinches nor in strongly deformed parts of the swells were we able to identify markers for dynamic recrystallization in the amphibolite. $s \lambda$ boudins are in many cases associated with biotite that can often be found enriched in the pinches, wrapping around the outer perimeter of the boudins. The amount of extensional strain by short-wavelength pinch-and-swell boudinage is with an estimated minimum of $50 \%$ considerably lower than that of the previous generation.

The general appearance of $s \lambda$ boudins suggest ductile deformation of both amphibolite and marble (yet with an effective viscosity contrast). However, occasionally these boudins are associated with brittle deformation features: some boudins of this generation exhibit localized low angle shear zones in the interboudin zones. The shear zones extend into the surrounding marble at $\sim 30^{\circ}$ to the layer with a microstructure analogous to domino boudins (see below). 

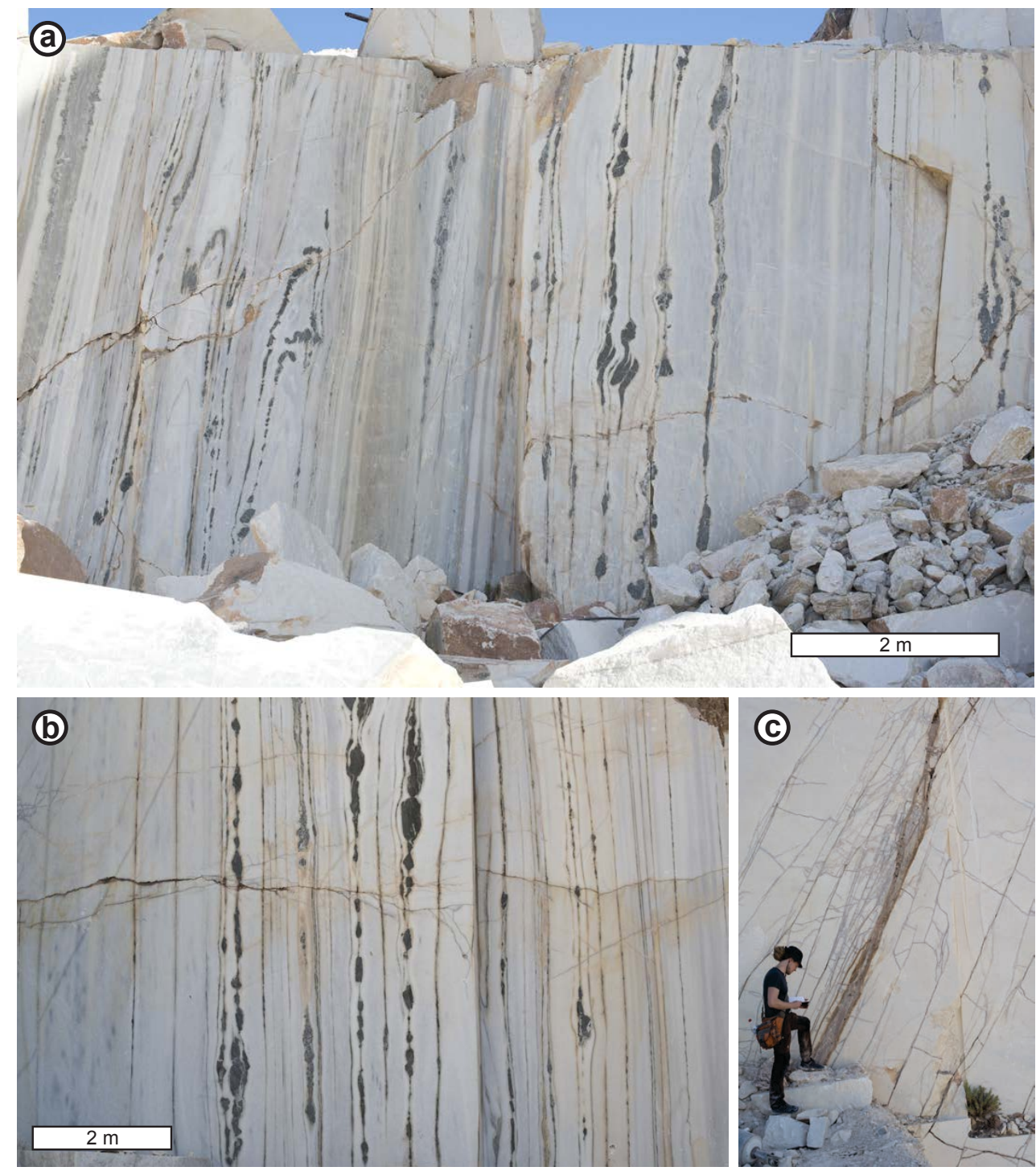

Figure 5. Examples of vertical wall exposures. (a) Isoclinal folds and pinch-and-swell boudins in a wall close to Location 7, view to the north. Banding of the marble is parallel to the amphibolite layers. (b) Pinch-and-swell structures in vertical walls result from the combination of $l \lambda$ and $s \lambda$ pinch-and-swell sets. In layer-normal 2-D sections it is challenging to distinguish between the two generations (Location 20, view to the south). (c) E-W-trending normal fault in the marble with a pronounced damage zone. The fault is filled with calcareous sinter (close to Location 8, view to the east).

Highly thinned-out pinches show a higher fraction of calcite grains in the amphibolite, up to the point that grains of amphibole and plagioclase are fully isolated in the marble matrix. The isolated grains have a grain size comparable with the amphibolite in the swells (Fig. 8d).

\subsection{Folds}

In many locations amphibolite layers are isoclinally folded, in asymmetric folds that occur in both $S$ and $Z$ chirality (both looking down or horizontally) (Fig. 6). They usually consist of one or two folded amphibolite layers, while adjacent amphibolites remain unfolded (Fig. 5). Their age relation- ship with the pinch-and-swell structures is not fully resolved, but they are crosscut and displaced by domino boudins, pegmatite dikes (compare Fig. 3a in Schenk et al., 2007) torn boudins and late hairline veins.

The fold axes have variable plunge to north or south. Normal to the fold axis the asymmetric folds rarely have limbs longer than $2 \mathrm{~m}$ (Figs. 5a, 6). In contrast, parallel to the fold axis they extend for several tens of metres, often over multiple quarry soles. The thickness of the amphibolite in the fold hinges is strongly increased relative to the limbs. The hinges are in some locations characterized by a weak foliation fan with statically recrystallized amphibolite and thin 

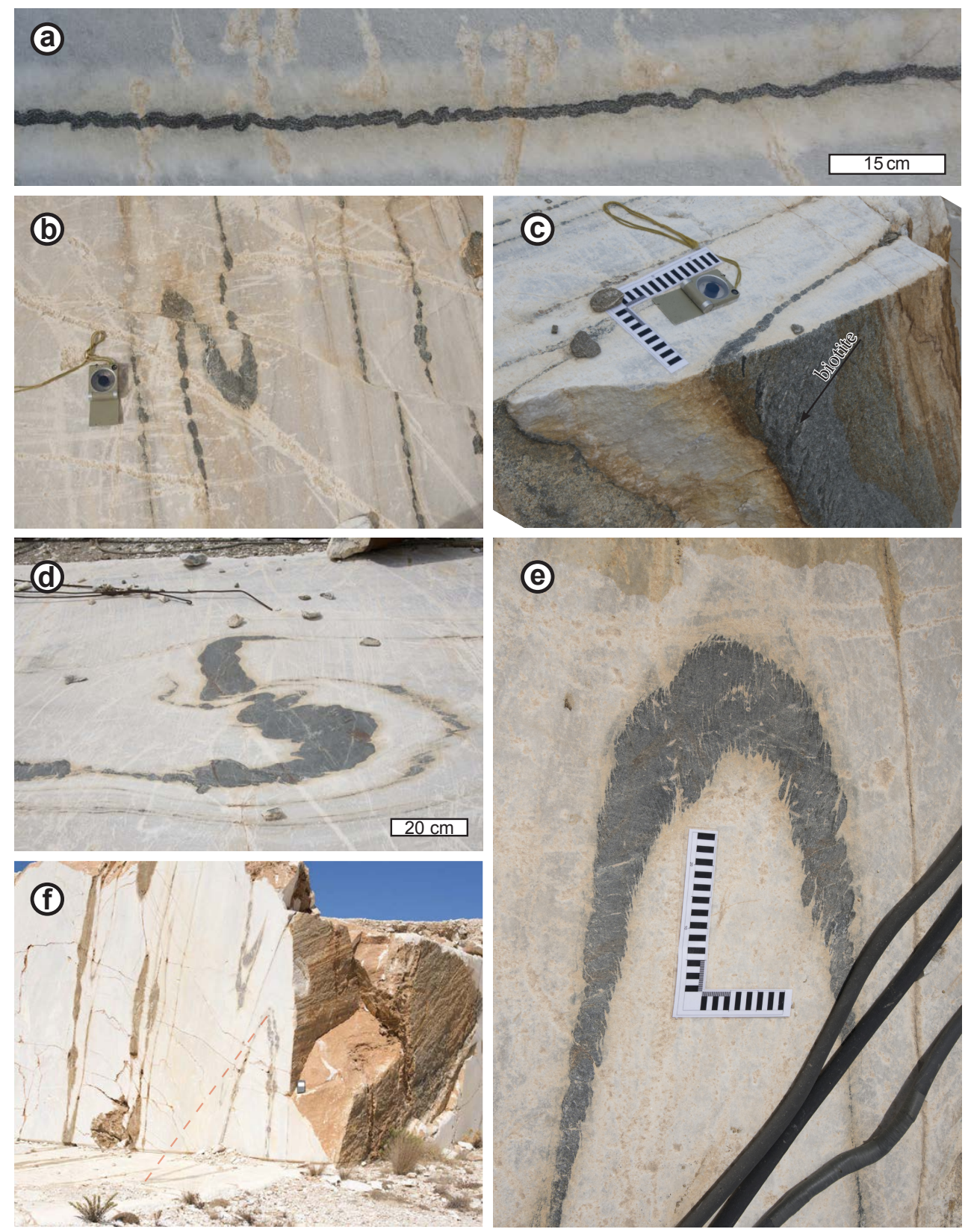

Figure 6. (a) Rare example of small-scale concentric open folds in an amphibolite layer. Much more common in the field area are asymmetric isoclinal folds. (b) Isoclinal $S$ fold displaced by a late E-W-trending oblique-slip fault. Both $S$ and $Z$ chiralities of folds are found in the study area. (c) Fold axis orientations vary strongly (see also Fig. 4); here the axis plunges steeply to the north. The layer-parallel cut of the limb exposes accumulations of biotite associated with the fold. (d) $S$ fold with multiple parasitic folds and increased amphibolite thickness in the limb (view to the west). Bright east-west-trending hairline veins are parallel in the fold limbs and reef and not necessarily orthogonal to the amphibolite layer. (e) Cuspate-lobate amphibolite-marble interfaces form foliation fans in some fold hinges. (f) South-dipping fold axis (dashed red line) in Location 15. The apparent lineation on the thin exposed amphibolite layer (above the fieldbook) is parallel to $l \lambda$.

calcite veins (Fig. 11). The foliation is often highlighted by cuspate-lobate amphibolite-marble interfaces. The cuspatelobate structures may be the result of interface buckling during folding (Biot, 1964). However, calcite inclusions in the extension of cusps in some folds suggest that they formed by shortening of a pre-existing boudin generation subnormal to the shortening axis of the fold (Fig. 11d). In the field, fold hinges are often associated with an increased occurrence of biotite. In the thin sections, cuspate-lobate structures sometimes show actinolitic rims with a shape-preferred orientation parallel to the interface, while the amphibolite in the cusps has a statically recrystallized microstructure (Fig. 11b). 

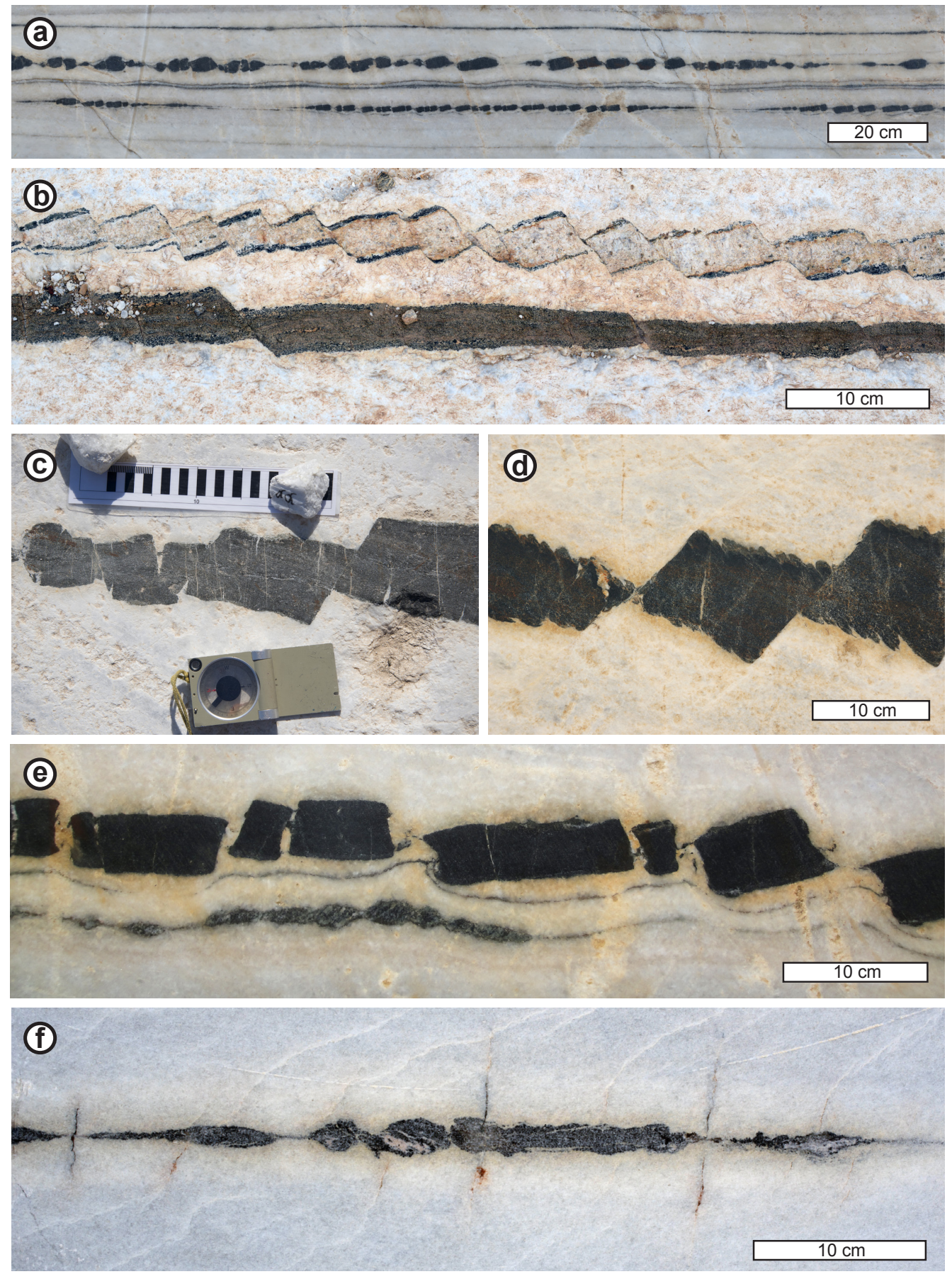

Figure 7. Brittle boudinage structures are best observed on quarry floors due to the generally high dips of the fracture planes. (a) Multiple layers of amphibole with two generations of boudin structures. The thin layers do not show any boudin structures while thicker layers boudinage in domino and torn boudins, overprinting long-wavelength pinch-and-swell boudins. The spacing of brittle boudins correlates with bed thickness, the lateral thickness variation results from older pinch-and-swell boudins. (b) Adjacent pegmatite and amphibolite layer with synthetic domino boudins. The length of the boudins in the amphibolite is exceptionally long. (c) Calcite- and chlorite-filled hairline veins crosscutting the shear planes of domino boudins. One of the fractures is an antithetic bending fracture. Usually the polarity of block rotation is very stable along a layer and antithetic fractures like this are rare in the study area. (d) Lobate amphibolite interface in the limb of an asymmetric fold crosscut and displaced by shear fractures. (e) Torn boudins with slightly concave faces $S_{\mathrm{ib}}$. A thin amphibolite layer highlights the deformation in the adjacent marble and shows the flow of marble into the interboudin zones. (f) Chlorite-filled mode-I hairline veins extending from the amphibolite layer into the surrounding marble. 

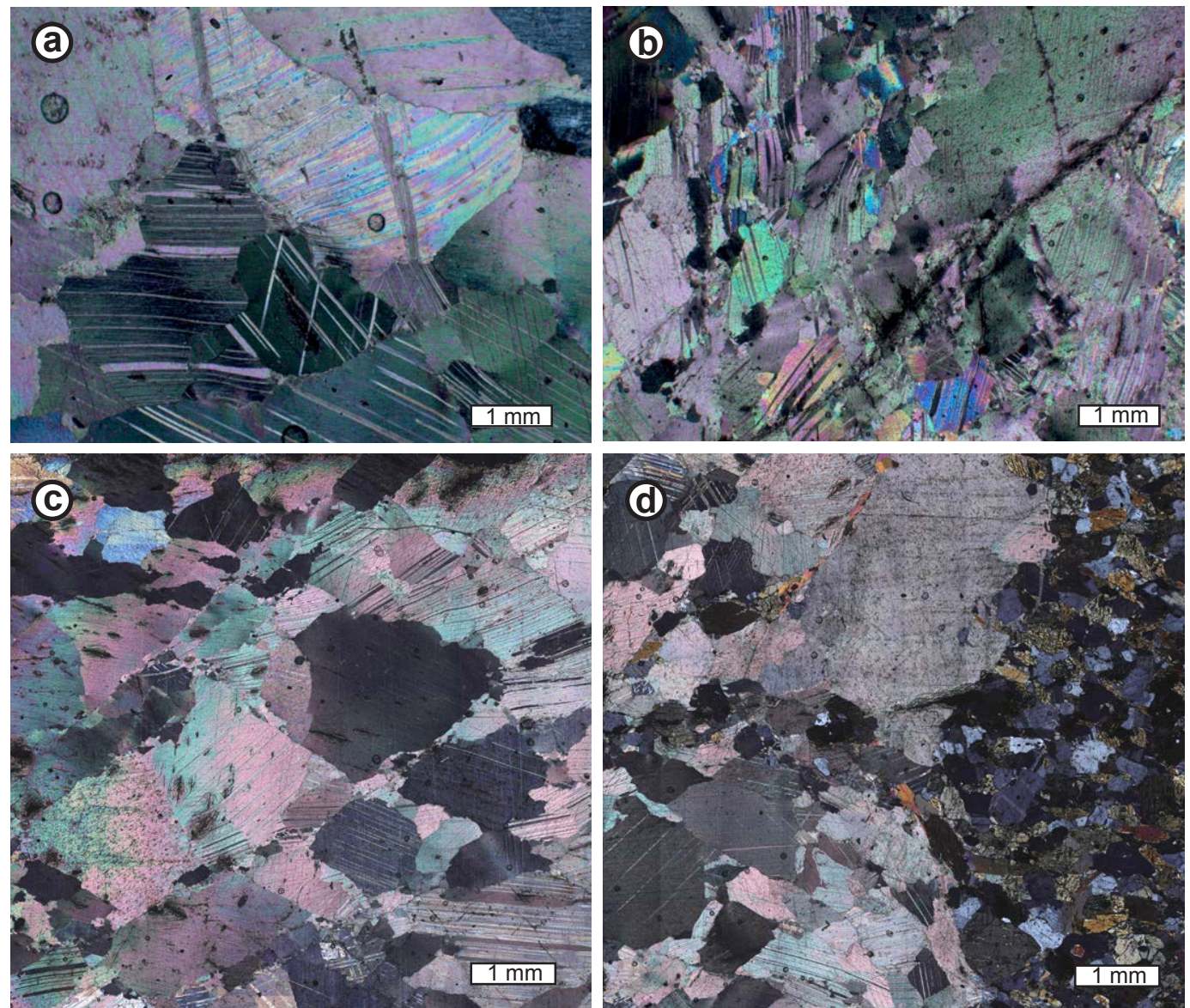

Figure 8. Micrographs of polished marble sections (thickness $\sim 10-15 \mu \mathrm{m}$, cross-polarized light) illustrating the marble microstructure: (a) the marble shows heterogeneous grain size, locally exceeding $10 \mathrm{~mm}$. Extensive twinning indicates late low-temperature deformation. (b) Top-left to bottom-right trending cluster of small-scale shear zones in the marble associated with domino boudinage (compare Fig. 12). In the shear zone the grain size is strongly reduced. Adjacent calcite grains show undulose extinction. (c) Orientation families with similar extinction behaviour are relicts of dynamically recrystallized larger grains. Lobate grain boundaries indicate high-temperature grain boundary migration. (d) Amphibole and plagioclase grains originating from the amphibolite on the right are intermingled with calcite grains in the neck of a pinch-and-swell boudin.

A rare variety of small-scale folds are concentric open folds, in marble close to Location 2 (Fig. 6a).

\subsection{Domino boudins}

Domino boudins are the oldest of three types of brittle boudins in the amphibolite (domino boudins, torn boudins, hairline veins), which are all characterized by sharply localized fractures but differ in failure mode, relative age and characteristics of the fractures. Domino boudins are characterized by asymmetric, rotated boudin blocks and sharply defined shear fractures. The shear fractures cut the amphibolite layers at an angle $\theta$ ranging from 60 to $90^{\circ}$ (defined as the angle between the fracture and boudin interface; see Goscombe et al., 2004). On both sides of the shear fractures in the amphibolite, thin shear zones extend into the surrounding marble as zones with sharp slip planes and grain size reduced to
$<50 \mu \mathrm{m}$ (Figs. 12, 13). With increasing distance from the amphibolite, these shear zones splay and curve towards parallel to the layer which indicates a layer-parallel shear component that is in line with forward vergent rotation of the boudin blocks.

The largest amount of displacement is parallel to the shear fractures $(D)$ while dilation between the block faces $(N)$ is generally low. The mineralogy of interboudin zones regularly contain, besides calcite, pyrite and sheared biotite. On exposed shear fractures, a normal- to oblique-slip slickenside lineation is commonly present. A full detachment of boudin blocks by large extension into asymmetric tapering boudins (Goscombe et al., 2004) is rare in the study area; in most amphibolite layers the domino blocks are still in contact with one another. The length-to-width ratio $(L / W)$ of this generation can be as low as 1 but more commonly it is of the order of 3-5 and in extreme cases $>8$. 

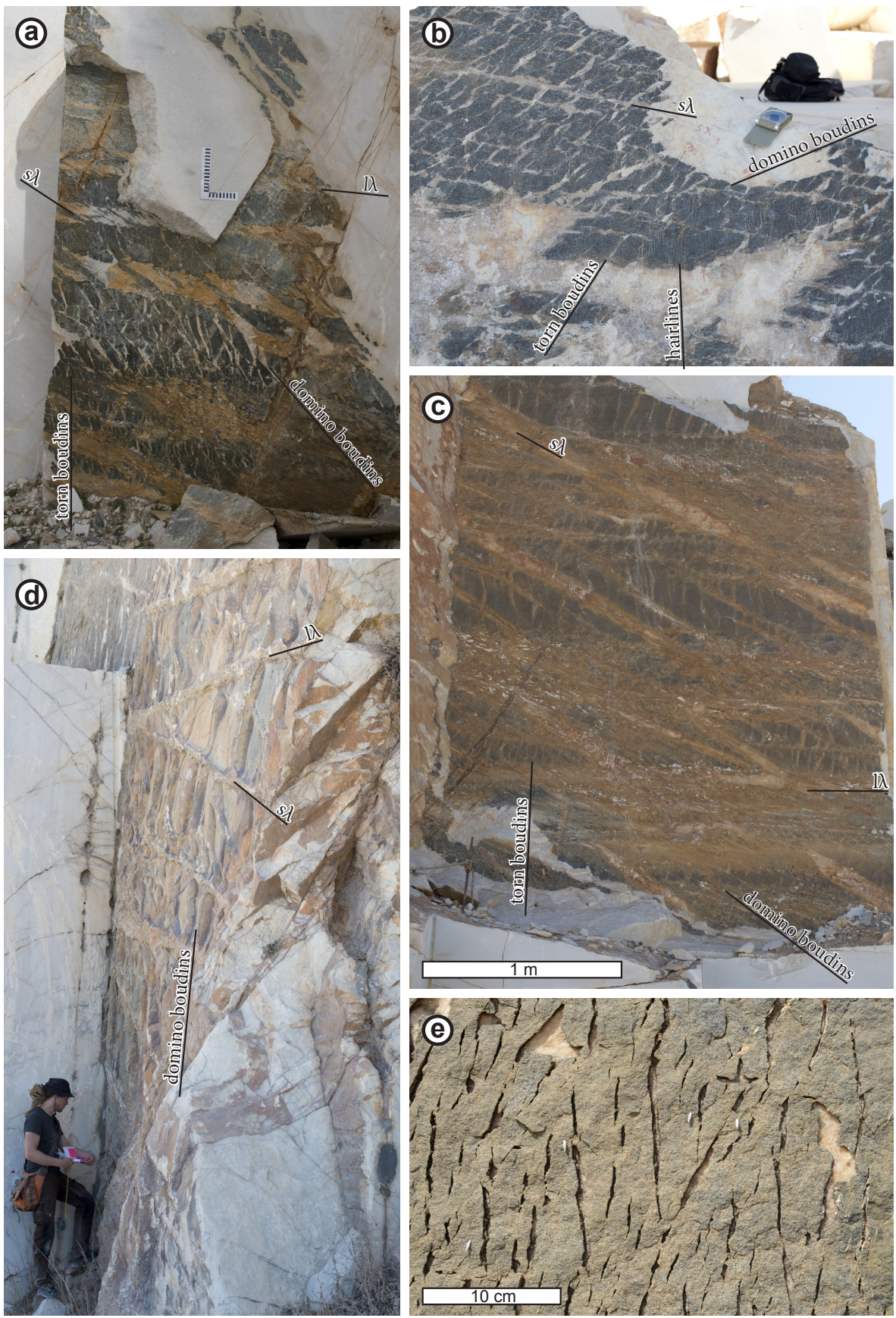

Figure 9. Mined blocks occasionally separate along amphibolite layers, exposing a planar view of the boudinaged layers. Such outcrops allow for investigating the interaction of multiple boudinage generations. (a) The subhorizontal long-wavelength boudinage $l \lambda$ is overprinted and slightly offset by the shorter-wavelength boudinage $s \lambda$. The direction of $s \lambda$ is consistent in the pinches and swells of $l \lambda$, indicating that $s \lambda$ is younger (view to the east). (b) Block split along a thin amphibolite layer. Domino boudins, torn boudins and hairline veins are clearly distinguishable. Torn boudins often terminate at the shear planes of domino boudins and at $s \lambda$ pinches. Hairline veins crosscut all structures and are only locally deviated by pre-existing domino shear planes. (c) The interfering $l \lambda$ and $s \lambda$ pinch-and-swell boudins result in a variation of the amphibolite thickness across a layer, which is partly reflected by the local spacing of younger torn boudins (view to the east). (d) Oblique view on an amphibolite marble interface. The pinches of $l \lambda$ and $s \lambda$ can be traced to an orthogonal cut in the neighbouring wall, allowing for 3-D inspection of the boudinaged layer. Remnants of slickensides can be locally found along the protruding faces of the domino boudins. (e) Two sets of torn boudins interacting in a weathered-out amphibolite layer (view to the east). 

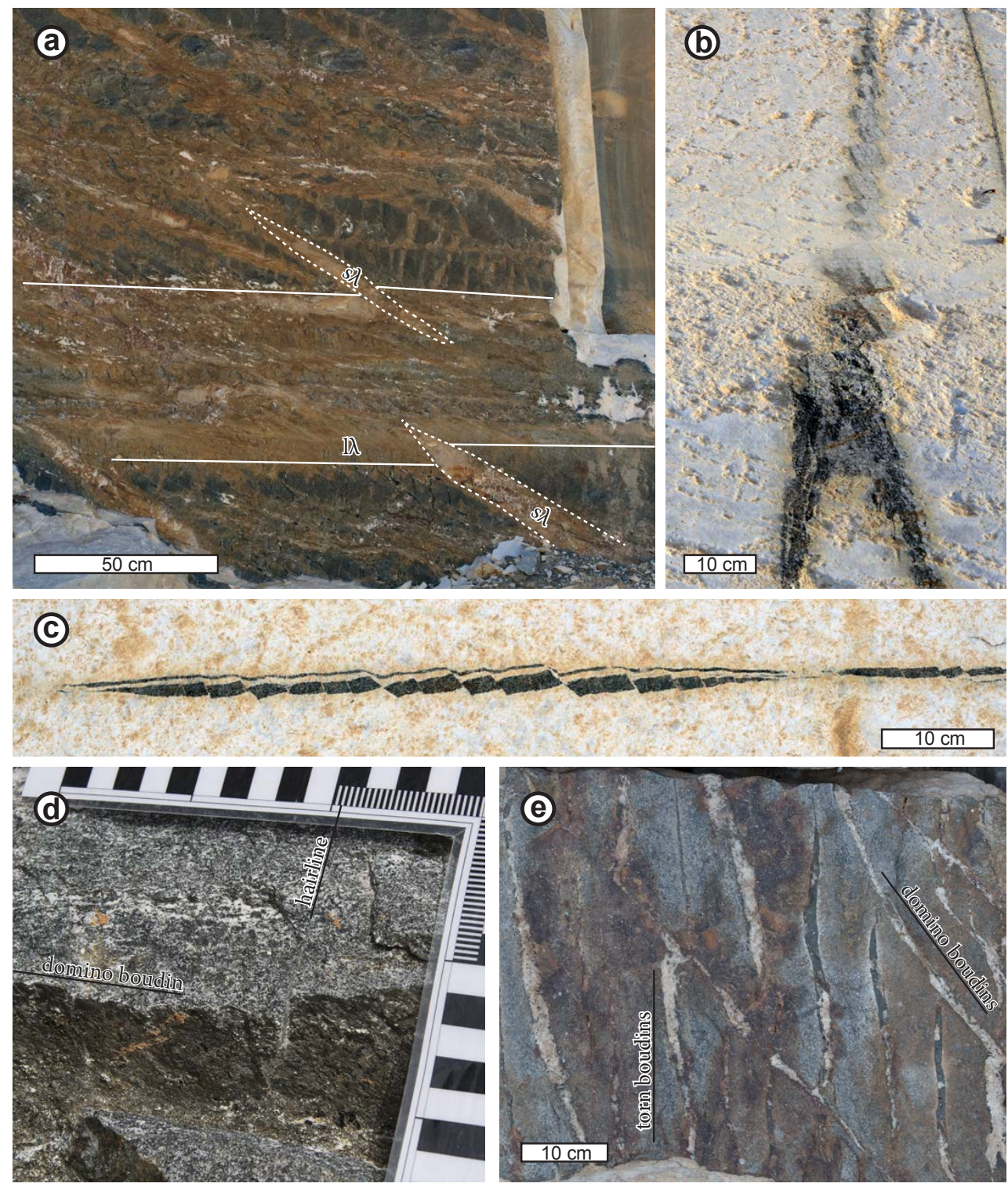

Figure 10. Outcrops showing clear age relationships between the structures. (a) Wall exposure of an amphibolite with intersecting $l \lambda$ and $s \lambda$ pinch-and-swell structures (view to east). $S \lambda$ pinches (dashed lines) displace the long axis of $l \lambda$ and have identical orientation in both $l \lambda$ swells and pinches. $S \lambda$ is therefore younger than $l \lambda$. (b) Elongated fold hinge displaced by domino boudins (view to south). (c) Domino boudinage of an older $s \lambda$ pinch. Note the change of spacing of domino boudins as the amphibolite thins out in the pinches. (d) Oblique view on a domino boudin slip plane crosscut by chlorite-filled hairline veins. Hairline veins are the youngest structures in the amphibolite, crosscutting all other structures (see also Figs. 6d, 7c). (e) Torn boudin necks filled with calcite and chlorite abut and deflect at pre-existing domino shear planes.

Looking down on the quarry floor, over distances up to $30 \mathrm{~m}$, within one amphibolite layer the sense of block rotation and shear displacement is commonly consistent. Along one amphibolite layer, antithetic shear fractures and block rotations in the opposite sense are rare. Adjacent amphibolite layers usually show the same sense of block rotation and shear displacement. However, both senses of block rotation and shear displacement are common and these bundles of layers with the same sense of block rotation and shear dis- placement are usually separated by layers without domino boudins.

Domino boudin inter-boudin planes $\left(S_{\mathrm{ib}}\right)$ are highly variable in strike, due to variance in $\theta$ as well as the occurrence of dextral and sinistral rotation and varying amounts of rotation. Domino inter-boudin planes have a rake between vertical and $\sim 60^{\circ}$ to the south. Due to the steep orientation domino boudins are much more obvious on the quarry floor then on vertical sections (Figs. 4, 7), which also is the case for 

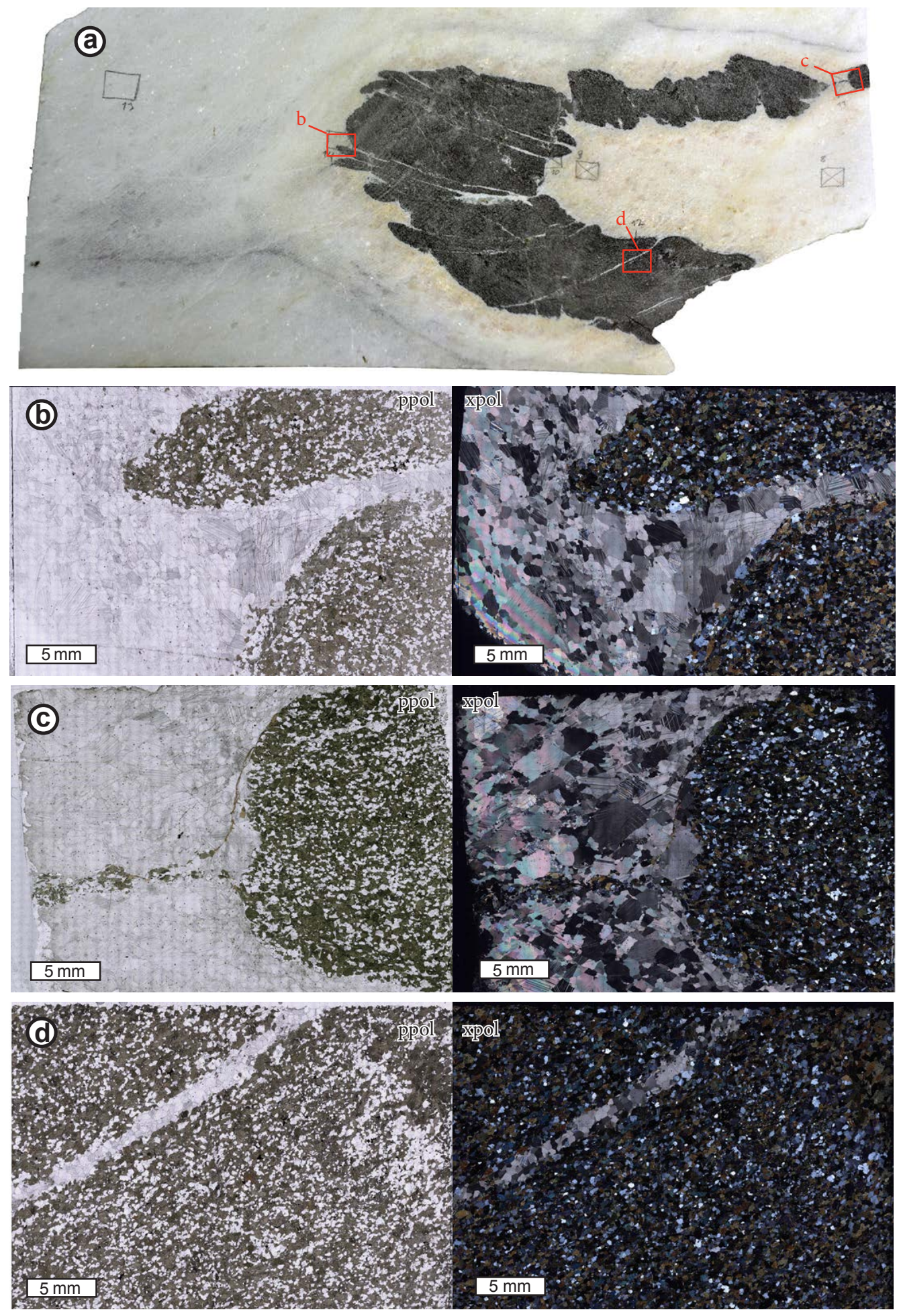

Figure 11. (a) Sample of a folded amphibolite layer. Red boxes show the thin section locations (b-d). Each section is shown in planepolarized light (left) and cross-polarized light (right). (b) Cuspate-lobate structure in the fold hinge. Although significant deformation can be expected in the lobes, the amphibolite shows no evidence of dynamic recrystallization. (c) Biotite wraps around the interface of the amphibolite and into the pinched neck of this boudin. (d) The calcite inclusions in the fold hinge contain fragments of amphibole and indicate boudins prior to folding. The calcite grain size in the inclusions is consistently smaller than in the marble. 

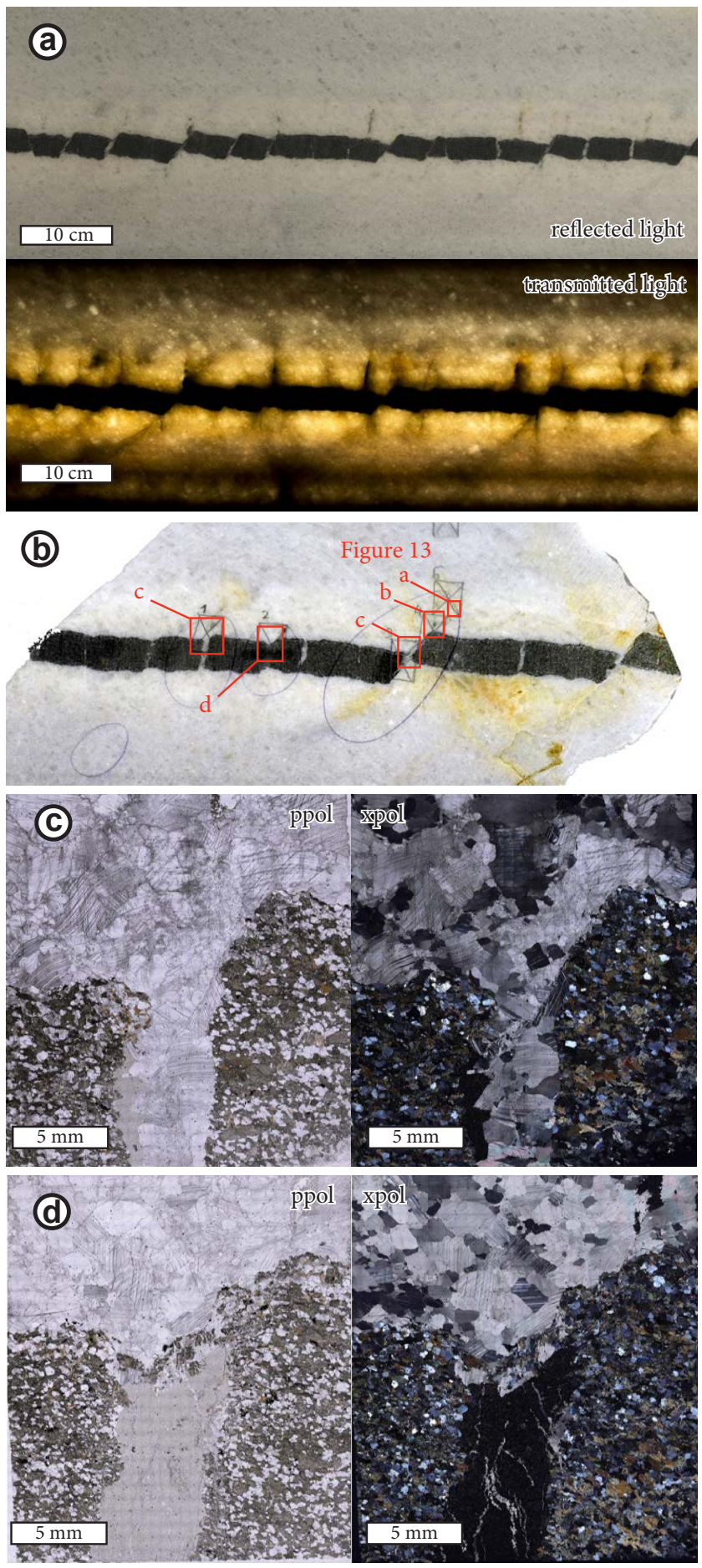

Figure 12. (a) Domino and torn boudins in a polished, $2 \mathrm{~cm}$ thick plate of marble. Close to the amphibolite layer the marble is more translucent. The transmitted light image highlights the shear zones extending from the domino boudins into the marble where they curve and splay. (b) Overview of thin-section locations of (c, d) and Fig. 13. The amphibolite layer is the same as shown in (a). (c) This torn boudin neck is filled mostly with calcite and contains a chlorite rim. Large grain size indicates that torn boudin necks form primarily as veins and not by intrusion of the surrounding marble. (d) Torn boudin neck filled with chlorite containing small calcite-filled veinlets. 

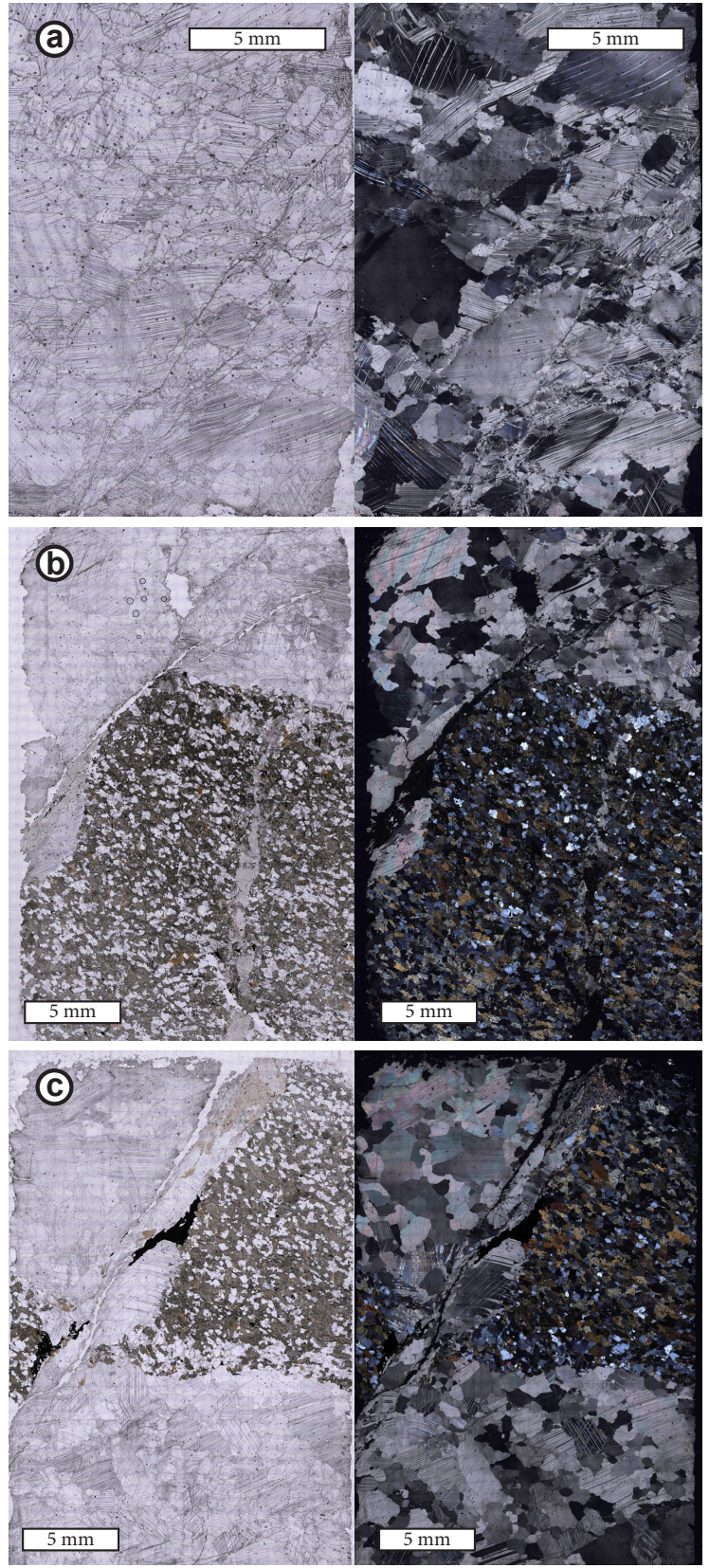

Figure 13. Neighbouring thin sections showing the localized deformation of a domino boudin (see Fig. 12 for location). Each section is shown in plane-polarized light (left) and cross-polarized light (right). (a) In the marble $\sim 2 \mathrm{~cm}$ away from the amphibolite numerous parallel shear zones can be found. Grains along the shear zones show intense twinning and undulose extinction. (b) At the interface of the amphibolite the shear zones have merged into a single slip zone; the fine-grained calcite fill easily breaks out during thinsection preparation. (c) The shear zone is partly filled with biotite and pyrite along the boudin face. The calcite in the zone between the separated blocks is intensely twinned and shows undulose extinction. Amphibole grains are heavily fractured. torn boudins and hairline veins. Domino boudins consistently crosscut and displace $s \lambda$, as well as (very rarely) small-scale isoclinal fold hinges. Domino boudins are the one boudin type that can be found with similar orientation to those in the amphibolite in nearly all pegmatites (compare Schenk et al., 2007). Their formation thus postdates both pinch-and-swell generations ( $s \lambda$ and $l \lambda$ ), small-scale folding, and pegmatite intrusion.

\subsection{Torn boudins}

Torn boudins are the second class of brittle boudins in the amphibolite. In contrast to the domino boudins, torn boudin always form in a Mode-I fracture normal to the amphibolite layer with sharp, intra- and intergranular fractures. The main component of displacement is dilatational, normal to the fracture, although locally minor systematic rotation $\left(<\sim 15^{\circ}\right)$ of the torn boudin blocks is present. In amphibolite layers that contain both torn boudins and domino boudins, the torn boudins show a lower spacing of the necks $(L / W=1.5-3)$ than the domino boudins.

In some amphibolite layers at least two generations of torn boudins are present, each with a stable direction, that intersect at a low angle or form wing cracks (Virgo et al., 2013, 2014) (Fig. 9e). The rake of the older set is usually subvertical while the younger set dips steeply to the south. The similar orientation makes cross-cutting relationships of torn and domino boudins rare in outcrop. Where a clear relationship was observable the domino boudins were consistently older than the torn boudins.

Torn boudin necks are filled with calcite and less commonly chlorite (Fig. 12). The calcite fill is blocky with grains often larger than the fracture aperture which include solid inclusion bands, indicating a crack-seal process. Features that would indicate solid-state flow of the surrounding marble into the opening fracture like a systematic grain size reduction in the surrounding marble or abrasion along the neck faces was never observed in thin section. However, deformation of passive markers indicate that flow of the surrounding marble into the boudin neck does play a role when the segregation of torn boudin becomes larger than a few millimetres (Fig. 7e).

\subsection{Hairline veins}

We count hairline veins as a boudin set in this study: their occurrence is always linked to amphibolite layers and the veins disrupt the amphibolite with a regular spacing, justifying the term boudinage, although the layer that is boudinaged is not in all cases limited to amphibolite. Hairline veins are ubiquitous in all amphibolite layers. They crosscut all other boudin and fold structures and thus represent the most recent deformation event in the amphibolite layers. Their orientation is quite stable throughout the study area, dipping $60^{\circ}$ towards the north. Hairline veins are purely opening-mode 
veins with no signs of shear displacement. The vein cement consists mostly of chlorite and less frequently calcite. Chlorite veins are locally present in pure, white marble bands directly adjacent to amphibolites. Nucleating preferentially at convex edges of domino boudins, chlorite-filled veins extend into the surrounding marble above and below (Fig. 7f). The orientation of the veins is parallel to the local, chlorite-filled hairline veins in the amphibolite. Hairline veins are parallel to the orientation of the most prominent set of large-scale E-W joints and faults in the marble. The faults (Fig. 5c) can have a displacement of a few metres, and they have a severalmetre-wide damage zone and a thin fault core in which open fractures are filled with fault breccia, fine-grained sediment and karst deposits.

\section{Discussion}

The five distinct generations of boudinage in N-S-trending, steeply dipping amphibolite layers may serve as a record of the internal deformation of the marbles from high-grade $\mathbf{M} 2_{b}$ metamorphic conditions ( $l \lambda$ pinch-and-swell boudins) over the pro- and retrograde path ( $s \lambda$ pinch-and-swell boudins, domino boudins and torn boudins) to finally shallow deformation (hairline veins, joints, faults). The decrease in temperature and pressure is reflected by the embrittlement of the amphibolite and marble through the stages of deformation and by the structurally associated minerals that change from biotite to chlorite and secondary calcite. A schematic representation of the structural elements is given in Fig. 14. In some cases the structures may appear as common chocolate tablet boudinage at first sight (see Fig. 9d). Yet, using this term here is an oversimplification since chocolate tablet boudinage is a special case of multiphase boudinage with two consecutive stages of layer-parallel brittle extension at a subnormal angle (Abe et al., 2013).

All boudin generations indicate E-W shortening with different orientations of layer-parallel extension, rotating in the plane of layering from vertical $(l \lambda)$ over south vergent ( $s \lambda$, domino boudins) and horizontal (domino boudins, torn boudins) to north vergent (hairline veins, joints). The strains involved decrease from $>100 \%$ elongation in $l \lambda$ over about $10 \%$ in domino boudins to $\sim 1 \%$ in the hairline veins. At the scale of observation, the structures are consecutive and discrete in orientation over many outcrops. None of the boudin sets shows a systematic change in orientation that indicates a continuous change in the extension direction. However, although the small-scale structures are obviously not continuous, they may still reflect a continuous large-scale rotating deformation under rheological evolution of the rocks (Marques et al., 2010). A compilation of our results is given in Fig. 15, relating the meso- and microstructural observations and our interpretation of the strain and temperature conditions to other structures and events. Before we discuss these results in the context of the geodynamic evolution of the

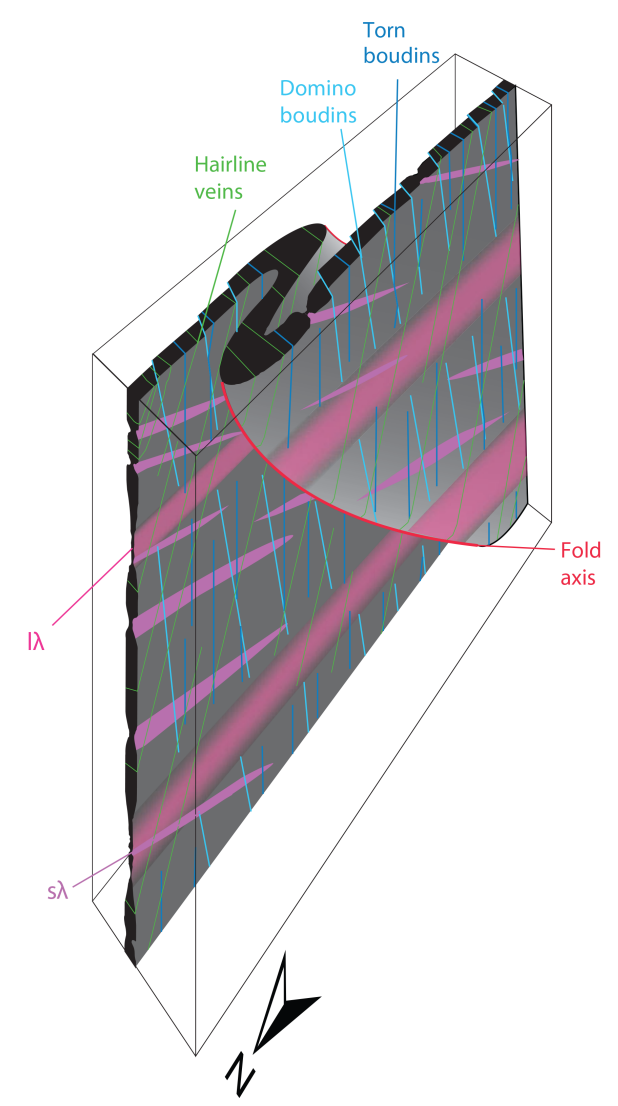

Figure 14. Schematic 3-D block diagram of an amphibolite layer and the containing structural elements. Note that domino boudins and torn boudins usually do not occur in the pinches of $l \lambda$. The orientation of the structures represent their mean orientation in the field. Spacing of the structures is not to scale.

Aegean, we examine aspects on our interpretation in more detail.

The origin of the amphibolite layers in the marbles is not conclusively known, but it is widely accepted that they already existed during the high-pressure metamorphism of M1 (Avigad, 1998; Bolhar et al., 2016; Buick and Holland, 1989; Martin et al., 2006). Their present-day N-S-trending subvertical orientation in the study area is interpreted to be a result of the high-strain viscoplastic deformation during the partial melting stage of the migmatite in $\mathrm{M} 2{ }_{b}$ (Kruckenberg et al., 2010, 2011; Vanderhaeghe, 2004). The marbles of our study area belong to the pinched synforms that formed in the high-strain zone between the subdomes of the migmatite dome. The orientation of the amphibolites is in good correspondence to the limbs of the interpreted large-scale structure in this zone. Furthermore, the long-wavelength pinch and swell $l \lambda$ (the oldest boudinage structure) is consistently parallel to the axis of this pinched synform. The boudins are interpreted to have formed by (only) vertical elongation of the large-scale limbs (see Ramsay, 1967) during E-W shortening in $\mathrm{M} 2{ }_{b}$ conditions. Considering that boudinage of the 


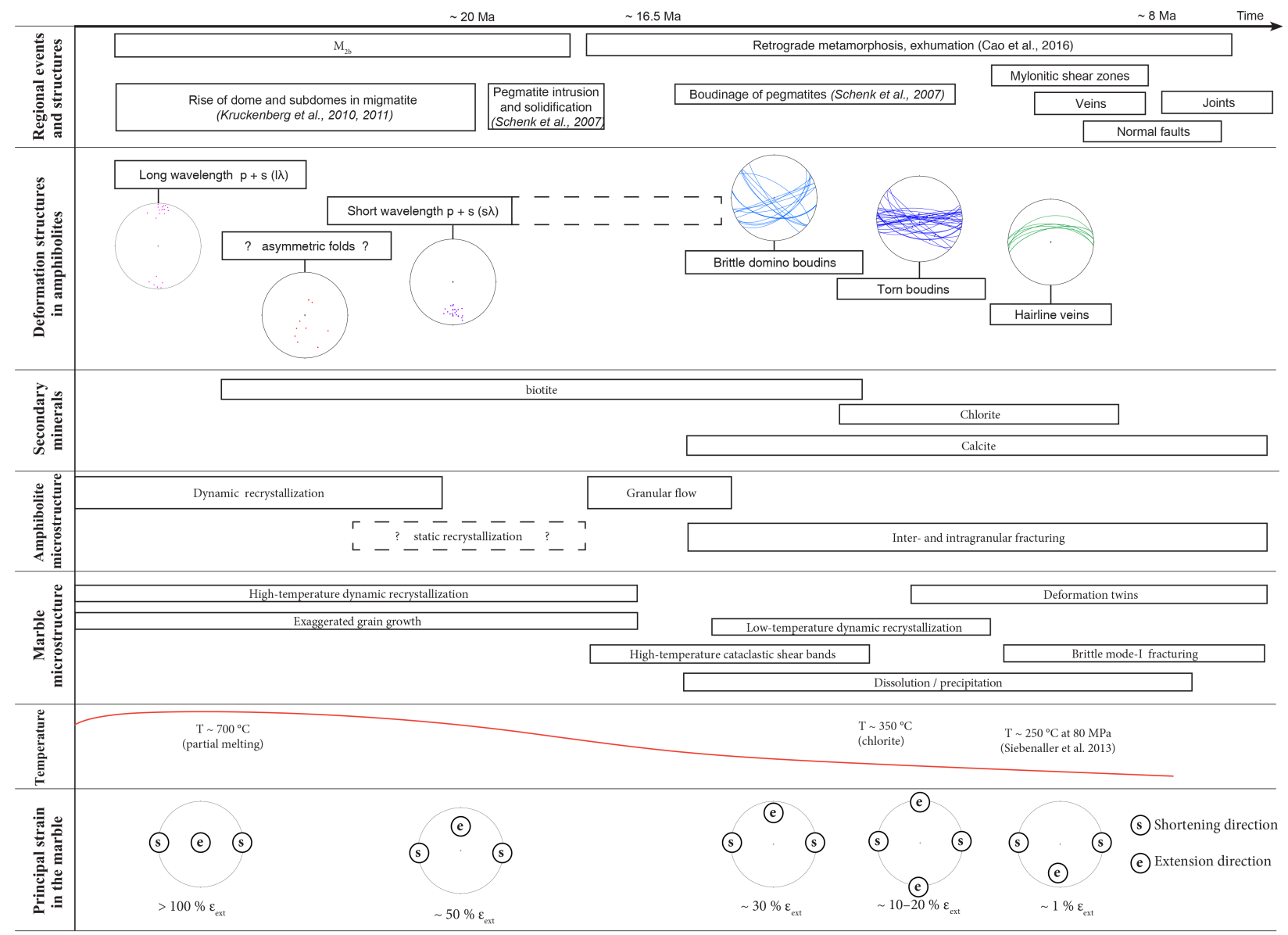

Figure 15. Overview of the results of this study in temporal relation to each other and to regional events. Note that only the relative order of events is considered and the time axis and temperature curve are not to scale. Results are grouped in rows; overlapping boxes are interpreted as contemporaneous. Data on temperature and regional events and structures are compiled from Buick and Holland (1991), Katzir (1999), Schenk et al. (2007), Kruckenberg et al. (2010, 2011) and Cao et al. (2016).

limbs first requires the formation of isoclinal folds leads to the conclusion that the amount of E-W shortening has to be much higher than what is reflected by the $l \lambda$ boudins.

\subsection{Strain inversion}

A prerequisite for the formation of boudins is a local layerparallel extension. Boudins can form in a variety of strain paths and vorticities. Especially domino boudins are widely recognized to form in non-coaxial deformation with the sense of block rotation indicating the direction of the shear component (Dabrowski and Grasemann, 2014; Goldstein, 1988; Mandal et al., 2007). We interpret the domino boudins of the study area to have formed in non-coaxial deformation conditions. However, since in parallel layers of amphibolite we can find both sinistral and dextral polarities of domino boudins, we are not able to infer a consistent sense of shear in the area. Our analysis (Fig. 15) is therefore limited to a broad identification of the principal axes of extension and shortening in the amphibolites and marbles. More work is needed for a more detailed study of the different generations of boudins, supported by texture analysis and piezometry. A potentially very useful tool for the analysis of strain in the domino boudins is analysis of the twins in the coarse-grained marble. Furthermore, a thorough investigation of the length-to-width ratio of each of the boudin generations can provide information on the evolution of the relative strength and pore pressure of the rocks (Marques et al., 2012; Pamplona and Rodrigues, 2011). However, in rocks with multiple interacting phases of boudinage such an analysis is challenging and has to be based on reliable 3-D data (Abe et al., 2013; Virgo et al., 2014, von Hagke et al., 2018).

\subsection{Folds}

Although we know from clear overprinting relationships that the small-scale isoclinal folds predate pegmatite intrusion and brittle boudins, their relation to the two types of pinchand-swell structures is not fully resolved. In some cases the folds seem to overprint the short-wavelength boudins and in 
other cases the fold axis is parallel to the $L_{\mathrm{b}}$ of this generation which would suggest that the folds and $s \lambda$ might be structurally related. Most of the observed folds are asymmetric, with changing $S$ or $Z$ chirality and a strong variation in the dip of the fold axis. Due to this strong variation in the orientation, these folds are not directly relatable to the large pinched synform discussed above. A structural relation between folds and boudins is not uncommon: one example is the abovementioned boudins that form in the stretching limbs of isoclinal folds. In analogue studies, Zulauf and Zulauf (2005) described two types of symmetric open folds forming in constrictional flattening strain, the first with a fold axis parallel to the layering and the extension direction and the second with a fold axis normal to the layering, folding in-plane boudinaged sections of the stronger layer.

Very similar folds to those of our study area were described in boudinaged aplitic dikes in marble by Poisel et al. (2016). These folds and boudins show mutual age relationships and are interpreted as coeval structures that formed in a general strain regime with components of layer-parallel stretching and shear (Bernhard Grasemann, personal communication, 2017). Another very similar example of coeval asymmetric folding and boudinage was observed in deformed quartz veins in a major shear zone by Pamplona et al. (2014). The asymmetric folds in the amphibolite are generally in good correspondence with non-coaxial folds forming in simple shear and general strain regimes (Alsop and Holdsworth, 2006, 2007; Cobbold and Quinquis, 1980; Marques et al., 2008; Ridley, 1986). Folds and domino boudins both suggest non-coaxial deformation in the study area. The possibility that $S$ folds are an overturned variation of $Z$ folds (compare Llorens et al., 2013) is considered unlikely: overturning these folds would either require a massive amount of layer-parallel shortening in the respective amphibolite or, alternatively, a larger-scale recumbent folding of multiple layers - including the previously folded layer. No indication for either alternative was found in the study area.

\subsection{Recrystallization in the amphibolite}

The microstructure of the amphibolite in folds and pinchand-swell boudins lack indicators for dynamic recrystallization despite considerable strain. This can either be explained by static recrystallization of the amphibolite after these deformation phases or by a non-crystal plastic deformation mechanism. Both possibilities are plausible: Gardner et al. (2015) have shown that pinch-and-swell structures can form by brittle failure in conjunction with material softening in the more competent layers. In fact, small-scale intergranular shear zones have been observed in the amphibolite around $s \lambda$ pinch-and-swell boudins (see Sect. 3.4). The increase of calcite in the amphibolite towards the pinches and the isolation of amphibolite grains floating in the marble matrix may indicate dilation and granular flow deformation of the amphibole and plagioclase grains as a deformation mechanism, fol- lowing disintegration of the grain assembly by intergranular fracturing. It is still unresolved whether $s \lambda$ pinch-and-swell boudins and possibly also folds are formed by this (mostly) brittle deformation mechanism. Another possibility is that the brittle features are a late overprint on a recrystallized amphibolite, formed during the evolution of the blocky boudins. The small-scale shear zones in the marble with mechanical twins and small recrystallized grains suggest temperatures below $300^{\circ} \mathrm{C}$ during formation of the blocky boudins (Burkhard, 1993). This part of the initial retrogression was suggested to occur from 20 to $16.6 \mathrm{Ma}$ (Siebenaller et al., 2013).

Apart from the lack of dynamic recrystallization microstructure, the foliation of the amphibolite in the limbs of small-scale folds is another feature that indicates static recrystallization. The foliation is inherited from a deformation fabric but overprinted by static grain growth so that it is at present reflected only by changes in the amphibolite composition (e.g. plagioclase content). Static recrystallization is possibly coeval with the pegmatite intrusion in the marbles. Firstly, all statically recrystallized structures are older than the pegmatites. Secondly, static recrystallization requires a time of deformation quiescence which was very likely the case in this phase: the pegmatites have intruded the marble in various directions, often subparallel to the amphibolite and reactivating the heterogeneity imposed by the amphibolite (Schenk et al., 2007). This requires $\sigma_{3}$ to be approximately normal to the amphibolite layers (Lister and Kerr, 1991; Rivalta et al., 2015), which is incompatible with a stress field able to produce boudins in these layers. The high variability of the pegmatite directions indicate variations of the principal stress orientation possibly related to a low differential stress, which is a prerequisite for static recrystallization.

\subsection{E-W shortening}

In the Aegean Sea, N-S- to NE-SW-trending fold axes indicative for $\mathrm{E}-\mathrm{W}$ shortening have been found on various islands in the central Aegean, including Andros, Tinos, Mykonos, Syros, Naxos and Paros (e.g. Angelier, 1977; Avigad et al., 2001; Gautier et al., 1993; Lecomte et al., 2010; Menant et al., 2013; Papanikolaou, 1980; Philippon et al., 2011, 2012; Urai et al., 1990). However, driving mechanisms, timing and amount of shortening in the E-W direction in the Aegean remain an ongoing matter of debate, and different hypotheses have been suggested. The controversy is partly related to interpretation of the nature of the MidCycladic Lineament, where orientation of lineations change abruptly across a narrow zone (Walcott and White, 1998a). This may be either interpreted as strike-slip faulting associated with crustal-scale shortening and block rotations (e.g. Jolivet et al., 2013; Philippon et al., 2011), or normal faulting in an overall extensional regime (Gautier et al., 1999; Hinsbergen and Schmid, 2012) including vertical axis rotations in the footwall (Malandri et al., 2017). Field evi- 
dence is controversial, as there seems that there is neither support for a major detachment (Brun et al., 2016; Jolivet et al., 2015; Philippon et al., 2014) nor is strike-slip faulting observed on Paros, where the Mid-Cycladic Lineament might be exposed (Malandri et al., 2017; Walcott and White, 1998a). Additional complexity is added due to interaction of slab roll-back with westward migration of the Anatolian Plate since $\sim 11 \mathrm{Ma}$ (Jolivet et al., 2013; Ring et al., 2010). It has been suggested that the Anatolian Plate is a main driver for observed E-W shortening, rendering the structures dominantly young if considering activity of the North Anatolian Fault (e.g. Menant et al., 2013). Earlier E-W shortening in the Aegean may be explained by the proto-North Anatolian Fault, as witnessed by ductile shearing in Turkey, that might have been linked to activity along the Mid-Cycladic Lineament (Philippon et al., 2014 and references therein). Alternatively, E-W shortening may be partly independent of the North Anatolian Fault and related to crustal attenuation and viscoplastic deformation during upward flow and partial melting of the crust and mantle in an overall extensional regime (Kruckenberg et al., 2010, 2011; Malandri et al., 2017). This scenario does not exclude late-stage shortening related to movement of the North Anatolian Fault, but most strain is accommodated earlier, locally constrained to the thermal domes.

On Naxos, there is evidence for two phases of E-W shortening. The oldest boudinage structures ( $l \lambda$ pinch-and-swell structures), which take up most of the strain, show vertical extension direction. This fits with the model of a pinched synform in between subdomes in the migmatite (Kruckenberg et al., 2011). In this model, E-W shortening is related to upper crustal extension and lower crustal convergent flow, and has been associated with $\mathrm{M} 2_{b}$ metamorphism. This socalled viscous collision does not require plate convergence, when domes form by upward deflection of horizontal, deep crustal flows during crustal extension (Kruckenberg et al., 2011; Rey et al., 2011). This model implies that most of the E-W shortening observed in the area is relatively old, much older than activity of the brittle North Anatolian Fault. During this deformation phase, viscoplastic flow is the dominant deformation process, driven by buoyancy and isostatic equilibration, so that no high differential stress is required to form the observed structures. Short-wavelength pinch-andswell boudinage $(s \lambda)$ accommodate less strain than $l \lambda$, and it is not clear whether they formed during or past peak metamorphism.

Younger structures mapped in the amphibolite, in particular all brittle boudin types as well as the open B3 folds outside the migmatite described in Urai et al. (1990), show N$\mathrm{S}$ stretching and shortening in the $\mathrm{E}-\mathrm{W}$ direction. All these structures formed post peak M2, thus on the retrograde path (see above). These structures are possibly linked with shortening due to motion on the North Anatolian Fault. This hypothesis could be tested for instance by dating minerals in the respective boudin necks. However, we note that the brittle structures only accommodate a small fraction of total strain in the amphibolite.

In summary, independent of local or regional importance of the signal, the E-W shortening history of Naxos requires two distinct and temporally separated E-W shortening phases. The first phase between 16 and $20 \mathrm{Ma}$ is dominated by viscoplastic flow and accommodates most of the total strain. After this deformation phase the amphibolite shows static recrystallization, implying little or no deformation. At a late stage, possibly related to movement of the North Anatolian Fault after $11 \mathrm{Ma}$, brittle boudins and open folds form.

This study provides a first look on the sequence of multiphase boudinage in the high-grade marbles of Naxos. Many aspects of the boudins in the amphibolites deserve further investigation. One example is the observation that layers thinner than a certain threshold do not localize boudins. This behaviour was recently reproduced for brittle-elastic layers in discrete element models of boudinage and is analogous to findings by Peters et al. (2015) on the initiation of pinch-andswell structures. Future studies in the area will hopefully deliver an in-depth analysis of the orientation, magnitude and vorticity of the regional and local stain field as well as an inversion of rheology for the different sets of structures.

\section{Conclusions}

The internal deformation history of high-grade marble bodies in the migmatitic centre of the Naxos metamorphic dome is recorded by multiphase boudinage and folding of amphibolite layers. We identified five generations of boudins with age relationships and orientations consistent across different marble bodies in the migmatite complex. The boudin generations are from oldest to youngest: two generations of pinchand-swell boudins, the first with a longer and the second with a shorter wavelength. These are followed by domino boudins, torn boudins and hairline veins reflecting embrittlement of the amphibolite layers. Outcrop-scale asymmetric folds predate torn boudins and hairline veins. Folds and domino boudins occur in both chiralities and indicate locally deviating shear sense. The long-wavelength pinch-andswell boudins are consistent with synmigmatic flow in the surrounding rocks. The timing and nature of static recrystallization in the amphibolite therefore remains elusive: if static recrystallization coincided with peak $\mathrm{M} 2{ }_{b}$, both pinch-andswell sets and folds must have formed on the prograde path of $\mathrm{M} 2{ }_{b}$. This implies that main deformation in the marbles occurred before the high internal deformation of the migmatite. Alternatively, if strong deformation in the migmatite and marbles are synchronous, the microstructure does not reflect static recrystallization by grain growth but must have formed by a different mechanism. Associated minerals and deformation microstructures indicate that brittle boudins formed on the retrograde path during cooling and exhumation. 
None of the outcrop-scale deformation structures in the high-grade marbles of the study area reflect the top-to-north shearing and vertical flattening that is dominant in the surrounding lithologies of the Naxos metamorphic core complex. E-W shortening is the main strain component for all described deformation structures. The extension direction evolves from vertical $(l \lambda)$ to south vergent $(s \lambda$ and domino boudins) to horizontal (torn boudins) to north vergent (hairline).

This study has been made possible by the exceptional outcrop conditions and highlights the wealth of information that can be gained from detailed analysis of boudinage structures.

Data availability. The structural raw data graphed in the stereonets are provided as a CSV file in the Supplement.

\section{The Supplement related to this article is available online at https://doi.org/10.5194/se-9-91-2018-supplement.}

Competing interests. The authors declare that they have no conflict of interest.

Acknowledgements. This work was funded by the Deutsche Forschungsgemeinschaft (DFG) in project "BoDy - Boudinage Dynamik" (UR 64/14-1). We thank Fernando O. Marques, Jorge Pamplona and K. Frings for their constructive comments on the paper, and the owners of the quarries around Kinidaros (Karpontini Bros - Naxian Marbles - karpontinibros.gr/ and Naxos Marble S. A. - naxos-marble.com) for access to the quarries, their hospitality and support of the fieldwork. We especially thank Yiannis Karpontinis for his help with this project, and many discussions about the Naxos Crystallina marble.

Edited by: Bernhard Grasemann

Reviewed by: Fernando Ornelas Marques and

Jorge Manuel Vieira Pamplona

\section{References}

Abe, S. and Urai, J. L.: Discrete element modeling of boudinage: Insights on rock rheology, matrix flow, and evolution of geometry, J. Geophys. Res., 117, B01407, https://doi.org/10.1029/2011JB008555, 2012.

Abe, S., Urai, J. L., and Kettermann, M.: Fracture patterns in nonplane strain boudinage - insights from 3-D discrete element models, J. Geophys. Res.-Solid Earth, 118, 1304-1315, https://doi.org/10.1002/jgrb.50126, 2013.

Alsop, G. I. and Holdsworth, R. E.: Sheath folds as discriminators of bulk strain type, J. Struct. Geol., 28, 1588-1606, 2006.

Alsop, G. I. and Holdsworth, R. E.: Flow perturbation folding in shear zones, Geol. Soc. Lond. Spec. Publ., 272, 75-101, 2007.
Andriessen, P. A. M., Boelrijk, N., Hebeda, E. H., Priem, H. N. A., Verdurnen, E. T., and Verschure, R. H.: Dating the events of metamorphism and granitic magmatism in the Alpine Orogen of Naxos (Cyclades, Greece), Contrib. Mineral. Petrol., 69, 215225, 1979.

Angelier, J.: Essai sur la neotectonique et les derniers stades tarditectoniques de l'arc egeen et de l'Egee meridionale, Bull. Soc. Geol. Fr., 7, 651-662, 1977.

Avigad, D.: High-pressure metamorphism and cooling on SE Naxos (Cyclades, Greece), Eur. J. Mineral., 10, 1309-1320, https://doi.org/10.1127/ejm/10/6/1309, 1998.

Avigad, D., Ziv, A., and Garfunkel, Z.: Ductile and brittle shortening, extension-parallel folds and maintenance of crustal thickness in the central, Tectonics, 20, 277-287, 2001.

Biot, M. A.: Theory of internal buckling of a confined multilayered structure, Geol. Soc. Am. Bull., 75, 563-568, 1964.

Bolhar, R., Ring, U., and Ireland, T. R.: Zircon in amphibolites from Naxos, Aegean Sea, Greece: origin, significance and tectonic setting, J. Metamor. Geol., 35.4, 413-434, https://doi.org/10.1111/jmg.12238, 2017.

Brichau, S., Ring, U., Ketcham, R. A., Carter, A., Stockli, D., and Brunel, M.: Constraining the long-term evolution of the slip rate for a major extensional fault system in the central Aegean, Greece, using thermochronology, Earth Planet. Sci. Lett., 241, 293-306, 2006.

Brun, J.-P., Faccenna, C., Gueydan, F., Sokoutis, D., Philippon, M., Kydonakis, K., and Gorini, C.: The two-stage Aegean extension, from localized to distributed, a result of slab rollback acceleration 1, Can. J. Earth Sci., 53, 1142-1157, 2016.

Buick, I. S.: Mylonite fabric development on Naxos, Greece, J. Struct. Geol., 13, 643-655, 1991.

Buick, I. S. and Holland, T. J. B.: The PTt path associated with crustal extension, Naxos, Cyclades, Greece, Geol. Soc. Lond. Spec. Publ., 43, 365-369, 1989.

Burkhard, M.: Calcite twins, their geometry, appearance and significance as stress-strain markers and indicators of tectonic regime: a review, J. Struct. Geol., 15, 351-368, https://doi.org/10.1016/0191-8141(93)90132-T, 1993.

Cao, S., Neubauer, F., Bernroider, M., Genser, J., Liu, J., and Friedl, G.: Low-grade retrogression of a high-temperature metamorphic core complex: Naxos, Cyclades, Greece, Geol. Soc. Am. Bull., 129, 93-117, 2017.

Casey, M., Dietrich, D., and Ramsay, J. G.: Methods for determining deformation history for chocolate tablet boudinage with fibrous crystals, Tectonophysics, 92, 211-239, https://doi.org/10.1016/0040-1951(83)90091-4, 1983.

Cobbold, P. R. and Quinquis, H.: Development of sheath folds in shear regimes, J. Struct. Geol., 2, 119-126, 1980.

Covey-Crump, S. J. and Rutter, E. H.: Thermally-induced grain growth of calcite marbles on Naxos Island, Greece, Contrib. Mineral. Petrol., 101, 69-86, 1989.

Dabrowski, M. and Grasemann, B.: Domino boudinage under layer-parallel simple shear, J. Struct. Geol., 68, 58-65, https://doi.org/10.1016/j.jsg.2014.09.006, 2014.

Duchene, S., Aissa, R., and Vanderhaeghe, O.: Pressuretemperature-time evolution of metamorphic rocks from Naxos (Cyclades, Greece): constraints from thermobarometry and Rb/Sr dating, Geodin. Acta, 19, 301-321, 2006. 
Dürr, S., Altherr, R., Keller, J., Okrusch, M., and Seidel, E.: The median Aegean crystalline belt: stratigraphy, structure, metamorphism, magmatism, Alps Apennines Hell., 38, 455-476, 1978.

Ebert, A., Rieke-Zapp, D., Herwegh, M., Ramseyer, K., Gnos, E., and Decrouez, D.: Microstructures of coarse-grained marbles, analyzed using a new technique based on the bireflectance of calcite, Tectonophysics, 463, 175-184, https://doi.org/10.1016/j.tecto.2008.09.041, 2009.

Gardner, R. L., Piazolo, S., and Daczko, N. R.: Pinch and swell structures: evidence for strain localisation by brittle-viscous behaviour in the middle crust, Solid Earth, 6, 1045-1061, https://doi.org/10.5194/se-6-1045-2015, 2015.

Gautier, P., Brun, J.-P., and Jolivet, L.: Structure and kinematics of Upper Cenozoic extensional detachment on Naxos and Paros (Cyclades Islands, Greece), Tectonics, 12, 1180-1194, https://doi.org/10.1029/93TC01131, 1993.

Gautier, P., Brun, J.-P., Moriceau, R., Sokoutis, D., Martinod, J., and Jolivet, L.: Timing, kinematics and cause of Aegean extension: a scenario based on a comparison with simple analogue experiments, Tectonophysics, 315, 31-72, 1999.

Ghosh, S. K.: Theory of chocolate tablet boudinage, J. Struct. Geol., 10, 541-553, https://doi.org/10.1016/0191-8141(88)90022-3, 1988.

Goldstein, A. G.: Factors affecting the kinematic interpretation of asymmetric boudinage in shear zones, J. Struct. Geol., 10, 707715, https://doi.org/10.1016/0191-8141(88)90078-8, 1988.

Goscombe, B. D. and Passchier, C. W.: Asymmetric boudins as shear sense indicators - an assessment from field data, J. Struct. Geol., 25, 575-589, 2003.

Goscombe, B. D., Passchier, C. W., and Hand, M.: Boudinage classification: end-member boudin types and modified boudin structures, J. Struct. Geol., 26, 739-763, https://doi.org/10.1016/j.jsg.2003.08.015, 2004.

Grasemann, B., Schneider, D. A., Stöckli, D. F., and Iglseder, C.: Miocene bivergent crustal extension in the Aegean: Evidence from the western Cyclades (Greece), Lithosphere, L164.1, 23 29, https://doi.org/10.1130/L164.1, 2011.

Harker, A.: IV. - On Local Thickening of Dykes and Beds by Folding, Geol. Mag., 6, 69-70, https://doi.org/10.1017/S0016756800175910, 1889.

Hinsbergen, D. J. and Schmid, S. M.: Map view restoration of Aegean-West Anatolian accretion and extension since the Eocene, Tectonics, 31, TC5005, https://doi.org/10.1029/2012TC003132, 2012.

Ingram, G. M. and Urai, J. L.: Top-seal leakage through faults and fractures: the role of mudrock properties, Geol. Soc. Lond. Spec. Publ., 158, 125-135, 1999.

Jansen, J. B. H.: Geological Map of Greece, Island of Naxos (1: 50,000), Inst. Geol. Miner. Resour. Athens, 1973.

Jansen, J. B. H.: Metamorphism on Naxos, Greece, Diss., Utrecht, 1977.

Jansen, J. B. H. and Schuiling, R. D.: Metamorphism on Naxos; petrology and geothermal gradients, Am. J. Sci., 276, 12251253, 1976.

John, B. E. and Howard, K. A.: Rapid extension recorded by cooling-age patterns and brittle deformation, Naxos, Greece, J. Geophys. Res.-Solid Earth, 100, 9969-9979, 1995.
Jolivet, L. and Brun, J.-P.: Cenozoic geodynamic evolution of the Aegean, Int. J. Earth Sci., 99, 109-138, https://doi.org/10.1007/s00531-008-0366-4, 2010.

Jolivet, L., Brun, J.-P., Gautier, P., Lallemant, S., and Patriat, M.: 3D-kinematics of extension in the Aegean region from the early Miocene to the Present, insights from the ductile crust, Bull. Soc. Geol. Fr., 165, 195-209, 1994.

Jolivet, L., Famin, V., Mehl, C., Parra, T., Aubourg, C., Hébert, R., and Philippot, P.: Strain localization during crustal-scale boudinage to form extensional metamorphic domes in the Aegean Sea, Geol. Soc. Am. Spec. Pap., 380, 185-210, 2004.

Jolivet, L., Faccenna, C., Huet, B., Lecomte, E., Labrousse, L., Denèle, Y., Le Pourhiet, L., Lacombe, O., Burov, E. B., Meyer, B., Suc, J., Popescu, S., Monié, P., Philippon, M., Gueydan, F., Brun, J., Paul, A., Salaün, G., and Armijo, R.: Aegean tectonics, a record of slab-overriding plate interactions, in AGU Fall Meeting Abstracts, available at: http://adsabs.harvard.edu/abs/ 2010AGUFM.T13G..04J (last access: 7 February 2018), 2010.

Jolivet, L., Faccenna, C., Huet, B., Labrousse, L., Le Pourhiet, L., Lacombe, O., Lecomte, E., Burov, E., Dentèle, Y., Brun, J.-P., Gueydan, F., Philippon, M., Paul, A., Salaün, G., Karabulut, H., Piromallo, C., Monié, P., Okay, A. I., Oberhänsli, R., Pourteau, A., Augier, R., Garenne, Leslie, and Driussi, O.: Aegean tectonics: Strain localisation, slab tearing and trench retreat, Tectonophysics, 597, 1-33, 2013.

Jolivet, L., Menant, A., Sternai, P., Rabillard, A., Arbaret, L., Augier, R., Laurent, V., Beaudoin, A., Grasemann, B., and Huet, B.: The geological signature of a slab tear below the Aegean, Tectonophysics, 659, 166-182, 2015.

Keay, S., Lister, G., and Buick, I.: The timing of partial melting, Barrovian metamorphism and granite intrusion in the Naxos metamorphic core complex, Cyclades, Aegean Sea, Greece, Tectonophysics, 342, 275-312, https://doi.org/10.1016/S00401951(01)00168-8, 2001.

Kenis, I., Sintubin, M., Muchez, P., and Burke, E. A. J.: The "boudinage" question in the High-Ardenne Slate Belt (Belgium): a combined structural and fluid-inclusion approach, Tectonophysics, 348, 93-110, https://doi.org/10.1016/S00401951(01)00251-7, 2002.

Krabbendam, M., Urai, J. L., and van Vliet, L. J.: Grain size stabilisation by dispersed graphite in a high-grade quartz mylonite: an example from Naxos (Greece), J. Struct. Geol., 25, 855-866, 2003.

Kruckenberg, S. C., Ferré, E. C., Teyssier, C., Vanderhaeghe, O., Whitney, D. L., Seaton, N. C., and Skord, J. A.: Viscoplastic flow in migmatites deduced from fabric anisotropy: An example from the Naxos dome, Greece, J. Geophys. Res.-Solid Earth, 115, B09401, https://doi.org/10.1029/2009JB007012, 2010.

Kruckenberg, S. C., Vanderhaeghe, O., Ferré, E. C., Teyssier, C., and Whitney, D. L.: Flow of partially molten crust and the internal dynamics of a migmatite dome, Naxos, Greece, Tectonics, 30, TC3001, https://doi.org/10.1029/2010TC002751, 2011.

Lecomte, E., Jolivet, L., Lacombe, O., Denèle, Y., Labrousse, L., and Le Pourhiet, L.: Geometry and kinematics of Mykonos detachment, Cyclades, Greece: Evidence for slip at shallow dip, Tectonics, 29, TC5012, https://doi.org/10.1029/2009TC002564, 2010.

Lister, J. R. and Kerr, R. C.: Fluid-mechanical models of crack propagation and their application to magma transport 
in dykes, J. Geophys. Res.-Solid Earth, 96, 10049-10077, https://doi.org/10.1029/91JB00600, 1991.

Lister, G. S., Banga, G., and Feenstra, A.: Metamorphic core complexes of Cordilleran type in the Cyclades, Aegean Sea, Greece, Geology, 12, 221, https://doi.org/10.1130/00917613(1984)12<221:MCCOCT>2.0.CO;2, 1984.

Llorens, M.-G., Bons, P. D., Griera, A., and Gomez-Rivas, E.: When do folds unfold during progressive shear?, Geology, 41, 563-566, 2013.

Lohest, M.: De l'origine des veines et des géodes des terrains primaires de Belgique, Ann. Soc. Géol. Belg. B, 36, 275-282, 1909.

Maeder, X., Passchier, C. W., and Koehn, D.: Modelling of segment structures: Boudins, bone-boudins, mullions and related singleand multiphase deformation features, J. Struct. Geol., 31, 817830, https://doi.org/10.1016/j.jsg.2009.05.013, 2009.

Malandri, C., Soukis, K., Maffione, M., Özkaptan, M., Vassilakis, E., Lozios, S., and Hinsbergen, D. J. J. van: Vertical-axis rotations accommodated along the Mid-Cycladic lineament on Paros Island in the extensional heart of the Aegean orocline (Greece), Lithosphere, 9, 78-99, https://doi.org/10.1130/L575.1, 2017.

Mandal, N., Dhar, R., Misra, S., and Chakraborty, C.: Use of boudinaged rigid objects as a strain gauge: Insights from analogue and numerical models, J. Struct. Geol., 29, 759-773, https://doi.org/10.1016/j.jsg.2007.02.007, 2007.

Marques, F. O., Guerreiro, S. M., and Fernandes, A. R.: Sheath fold development with viscosity contrast: Analogue experiments in bulk simple shear, J. Struct. Geol., 30, 1348-1353, https://doi.org/10.1016/j.jsg.2008.07.001, 2008.

Marques, F. O., Burg, J.-P., Lechmann, S. M., and Schmalholz, S. M.: Fluid-assisted particulate flow of turbidites at very low temperature: A key to tight folding in a submarine Variscan foreland basin of SW Europe, Tectonics, 29, TC2005, https://doi.org/10.1029/2008TC002439, 2010.

Marques, F. O., Fonseca, P. D., Lechmann, S., Burg, J.-P., Marques, A. S., Andrade, A. J. M., and Alves, C.: Boudinage in nature and experiment, Tectonophysics, 526-529(Supplement C), 8896, https://doi.org/10.1016/j.tecto.2011.08.017, 2012.

Martin, L., Duchêne, S., Deloule, E., and Vanderhaeghe, O.: The isotopic composition of zircon and garnet: a record of the metamorphic history of Naxos, Greece, Lithos, 87, 174-192, 2006.

Martin, L. A., Duchêne, S., Deloule, E., and Vanderhaeghe, O.: Mobility of trace elements and oxygen in zircon during metamorphism: consequences for geochemical tracing, Earth Planet. Sci. Lett., 267, 161-174, 2008.

Menant, A., Jolivet, L., Augier, R., and Skarpelis, N.: The North Cycladic Detachment System and associated mineralization, Mykonos, Greece: Insights on the evolution of the Aegean domain, Tectonics, 32, 433-452, 2013.

Mercier, J. L., Carey, E., Philip, H., and Sorel, D.: La néotectonique plio-quaternaire de l'arc égéen externe et de la mer Egée et ses relations avec la séismicité, Bull. Soc. Geol. Fr., 7, 355-372, 1976.

Pamplona, J. and Rodrigues, B. C.: Kinematic interpretation of shearband boudins: New parameters and ratios useful in HT simple shear zones, J. Struct. Geol., 33, 38-50, https://doi.org/10.1016/j.jsg.2010.10.004, 2011.

Pamplona, J., Rodrigues, B. C., and Fernández, C.: Folding as a precursor of asymmetric boudinage in shear zones affecting migmatitic terranes, Geogaceta, 55, 15-18, 2014.
Papanikolaou, D.: Contribution to the geology of Aegean Sea: the island of Paros, Ann. Geol. Pays Hell., 30, 65-96, 1980.

Peters, M., Berger, A., and Herwegh, M.: Microstructural evidence for the initiation of pinch-and-swell structures in ductile rocks, Geotecton. Res., 97, 153-153, 2015.

Philippon, M., Brun, J.-P., and Gueydan, F.: Tectonics of the Syros blueschists (Cyclades, Greece): From subduction to Aegean extension, Tectonics, 30, TC4001, https://doi.org/10.1029/2010TC002810, 2011.

Philippon, M., Brun, J.-P., and Gueydan, F.: Deciphering subduction from exhumation in the segmented Cycladic Blueschist Unit (Central Aegean, Greece), Tectonophysics, 524-525, 116-134, https://doi.org/10.1016/j.tecto.2011.12.025, 2012.

Philippon, M., Brun, J.-P., Gueydan, F., and Sokoutis, D.: The interaction between Aegean back-arc extension and Anatolia escape since Middle Miocene, Tectonophysics, 631, 176-188, 2014.

Price, N. J. and Cosgrove, J. W.: Analysis of Geological Structures, Cambridge University Press, 1990.

Poisel, R., Kolenprat, B., Bertagnoli, M., Ahmadabadi, M., Grasemann, B., and Hödlmoser, N.: The rockslide hazard in the former quarry near Spitz and its foreland/Die Felssturzgefahr im ehemaligen Tagebau Spitz ad Donau und dessen Vorland, Geomech. Tunn., 9, 497-507, 2016.

Pollard, D. D. and Fletcher, R. C.: Fundamentals of structural geology, Cambridge University Press, 2005.

Ramberg, H.: Natural and Experimental Boudinage and Pinch-and-Swell Structures, J. Geol., 63, 512-526, https://doi.org/10.1086/626293, 1955.

Ramsay, A. C.: The Geology of North Wales. Memoirs of the Geological Survey of Great Britain 3, available at: https://www.abebooks.co.uk/book-search/title/ the-geology-of-north-wales/author/ramsay-a-c/ (last access: 5 June 2017), 1881.

Ramsay, J. G.: Folding and Fracturing of Rocks., McGrawHill, New York, 568, Scientific Research Publish, available at: http://www.scirp.org/ (S(351jmbntvnsjt1aadkposzje))/reference/ ReferencesPapers.aspx?ReferenceID=1688431 (last access: 6 June 2017), 1967.

Reber, J. E., Schmalholz, S. M., and Burg, J.-P.: Stress orientation and fracturing during three-dimensional buckling: Numerical simulation and application to chocolate-tablet structures in folded turbidites, SW Portugal, Tectonophysics, 493, 187-195, 2010.

Renjith, A. R., Mamtani, M. A., and Urai, J. L.: Fabric analysis of quartzites with negative magnetic susceptibility - Does AMS provide information of SPO or CPO of quartz?, J. Struct. Geol., 82(Supplement C), 48-59, https://doi.org/10.1016/j.jsg.2015.11.005, 2016.

Rey, P. F., Teyssier, C., Kruckenberg, S. C., and Whitney, D. L.: Viscous collision in channel explains double domes in metamorphic core complexes, Geology, 39, 387-390, 2011.

Ridley, J.: Parallel stretching lineations and fold axes oblique to a shear displacement direction - a model and observations, J. Struct. Geol., 8, 647-653, https://doi.org/10.1016/01918141(86)90070-2, 1986.

Ring, U. and Layer, P. W.: High-pressure metamorphism in the Aegean, eastern Mediterranean: Underplating and exhumation from the Late Cretaceous until the Miocene to Recent above 
the retreating Hellenic subduction zone, Tectonics, 22, 1022, https://doi.org/10.1029/2001TC001350, 2003.

Ring, U., Glodny, J., Will, T., and Thomson, S.: The Hellenic subduction system: high-pressure metamorphism, exhumation, normal faulting, and large-scale extension, Annu. Rev. Earth Planet. Sci., 38, 45-76, 2010.

Rivalta, E., Taisne, B., Bunger, A. P., and Katz, R. F.: A review of mechanical models of dike propagation: Schools of thought, results and future directions, Tectonophysics, 638(Supplement C), 1-42, https://doi.org/10.1016/j.tecto.2014.10.003, 2015.

Schenk, O., Urai, J. L., and Evans, B.: The effect of water on recrystallization behavior and grain boundary morphology in calciteobservations of natural marble mylonites, J. Struct. Geol., 27, 1856-1872, https://doi.org/10.1016/j.jsg.2005.05.015, 2005.

Schenk, O., Urai, J. L., and van der Zee, W.: Evolution of boudins under progressively decreasing pore pressure - A case study of pegmatites enclosed in marble deforming at high grade metamorphic conditions, Naxos, Greece, Am. J. Sci., 307, 1009-1033, https://doi.org/10.2475/07.2007.03, 2007.

Schmalholz, S. M. and Maeder, X.: Pinch-and-swell structure and shear zones in viscoplastic layers, J. Struct. Geol., 37, 75-88, 2012.

Schmalholz, S. M., Schmid, D. W., and Fletcher, R. C.: Evolution of pinch-and-swell structures in a power-law layer, J. Struct. Geol., 30, 649-663, https://doi.org/10.1016/j.jsg.2008.01.002, 2008.

Seward, D., Vanderhaeghe, O., Siebenaller, L., Thomson, S., Hibsch, C., Zingg, A., Holzner, P., Ring, U. and Duchêne, S.: Cenozoic tectonic evolution of Naxos Island through a multi-faceted approach of fission-track analysis, Geol. Soc. Lond. Spec. Publ., 321, 179-196, https://doi.org/10.1144/SP321.9, 2009.

Siebenaller, L., Boiron, M.-C., Vanderhaeghe, O., Hibsch, C., Jessell, M. W., Andre-Mayer, A.-S., France-Lanord, C., and Photiades, A.: Fluid record of rock exhumation across the brittleductile transition during formation of a Metamorphic Core Complex (Naxos Island, Cyclades, Greece), J. Metamorph. Geol., 31, 313-338, https://doi.org/10.1111/jmg.12023, 2013.

Urai, J. L. and Feenstra, A.: Weakening associated with the diaspore-corundum dehydration reaction in metabauxites: an example from Naxos (Greece), J. Struct. Geol., 23, 941-950, https://doi.org/10.1016/S0191-8141(00)00165-6, 2001.

Urai, J. L., Schuiling, R. D., and Jansen, J. B. H.: Alpine deformation on Naxos (Greece), Geol. Soc. Lond. Spec. Publ., 54, 509-522, 1990.
Vanderhaeghe, O.: Structural development of the Naxos migmatite dome, Geol. Soc. Am. Spec. Pap., 380, 211-227, 2004.

Van Noten, K. and Sintubin, M.: Linear to non-linear relationship between vein spacing and layer thickness in centimetre-to decimetre-scale siliciclastic multilayers from the High-Ardenne slate belt (Belgium, Germany), J. Struct. Geol., 32, 377-391, 2010.

Virgo, S., Abe, S., and Urai, J. L.: Extension fracture propagation in rocks with veins: Insight into the crack-seal process using Discrete Element Method modeling, J. Geophys. Res.-Solid Earth, 118, 5236-5251, https://doi.org/10.1002/2013JB010540, 2013.

Virgo, S., Abe, S., and Urai, J. L.: The evolution of crack seal vein and fracture networks in an evolving stress field: Insights from Discrete Element Models of fracture sealing, J. Geophys. Res.-Solid Earth, 119, 8708-8727, https://doi.org/10.1002/2014JB011520, 2014.

Virgo, S., Heup, T., Urai, J. L., and Berlage, T.: Virtual Petrography (ViP)-A virtual microscope for the geosciences, in EGU General Assembly Conference Abstracts, Vol. 18, p. 14669, available at: http://adsabs.harvard.edu/abs/2016EGUGA..1814669V, 2016.

von Hagke, C., Bamberg, B., Virgo, S., and Urai, J. L.: Outcropscale tomography: insights into the 3D structure of multiphase boudins, J. Struct. Geol., in press, 2018.

Walcott, C. and White, S.: Constraints on the kinematics of postorogenic extension imposed by stretching lineations in the Aegean region, Tectonophysics, 298, 155-175, 1998a.

Walcott, C. R. and White, S. H.: Constraints on the kinematics of post-orogenic extension imposed by stretching lineations in the Aegean region, Tectonophysics, 298, 155-175, https://doi.org/10.1016/S0040-1951(98)00182-6, 1998b.

Wijbrans, J. R. and McDougall, I.: Metamorphic evolution of the Attic Cycladic Metamorphic Belt on Naxos (Cyclades, Greece) utilizing 40Ar/39Ar age spectrum measurements, J. Metamorph. Geol., 6, 571-594, 1988.

Zulauf, J. and Zulauf, G.: Coeval folding and boudinage in four dimensions, J. Struct. Geol., 27, 1061-1068, 2005.

Zulauf, G., Gutiérrez-Alonso, G., Kraus, R., Petschick, R., and Potel, S.: Formation of chocolate-tablet boudins in a foreland fold and thrust belt: A case study from the external Variscides (Almograve, Portugal), J. Struct. Geol., 33, 1639-1649, 2011 a.

Zulauf, J., Zulauf, G., Kraus, R., Gutiérrez-Alonso, G., and Zanella, F.: The origin of tablet boudinage: Results from experiments using power-law rock analogs, Tectonophysics, 510, 327-336, $2011 b$. 